\title{
Does immigration decrease far-right popularity? Evidence from Finnish municipalities
}

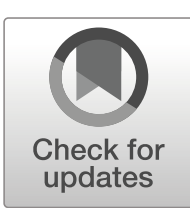

\author{
Jakub Lonsky ${ }^{1}$ (D)
}

Received: 2 May 2019 / Accepted: 10 June 2020 / Published online: 7 July 2020

(C) The Author(s) 2020

\begin{abstract}
Across Europe, far-right parties have made significant electoral gains in recent years. Their anti-immigration stance is considered one of the main factors behind their success. Using data from Finland, this paper studies the effect of immigration on voting for the far-right Finns Party on a local level. Exploiting a convenient setup for a shiftshare instrument, I find that a 1 percentage point increase in the share of foreign citizens in a municipality decreases the Finns Party's vote share by 3.4 percentage points. Placebo tests using pre-period data confirm this effect is not driven by persistent trends at the municipality level. The far-right votes lost to immigration are captured by the two pro-immigration parties. Turning to potential mechanisms, immigration is found to increase voter turnout, potentially activating local pro-immigration voters. Moreover, the negative effect is only present in municipalities with high initial exposure to immigrants, consistent with the intergroup contact theory. Finally, I also provide some evidence for the welfare-state channel as a plausible mechanism behind the main result.
\end{abstract}

Keywords Immigration · Far-right · Political economy · Voting

JEL Classification $\mathrm{H} 71 \cdot \mathrm{J} 15 \cdot \mathrm{J} 61 \cdot \mathrm{P} 16$

Responsible editor: Klaus F. Zimmermann

Jakub Lonsky

jal228@pitt.edu

1 Centre on Migration, Policy and Society (COMPAS), University of Oxford, 58 Banbury Road, Oxford, OX2 6QS, UK 


\section{Introduction}

The popularity of far-right (sometimes also referred to as populist radical right) ${ }^{1}$ parties across Europe has been rising rapidly in recent years. The latest political developments in Europe-such as the UK's exit from the European Union-suggest that the surge of the far-right could have significant negative economic and political consequences for the entire continent. The rise of the far-right appears to be driven-in large part-by immigration. Since the early 1990s, Europe has experienced significant migration flows. First was the East to West migration from post-communist countries that began with the fall of the Soviet Union, and accelerated after the EU enlargements in the 2000s. Recent years saw a large inflow of asylum seekers from Asia and Africa fueled by a number of armed conflicts. Both of these immigration shocks likely kindled anti-immigrant sentiments across the continent, contributing to an unprecedented wave of electoral success among far-right parties.

This paper studies the effect of immigration on voting for the far-right on a local (municipality) level. This micro effect is facilitated through the personal contact between natives and immigrants as well as the perceived impact of foreign in-migration on local communities. By contrast, the macro effect of national immigrant inflows refers to the salience of migration in the national social and political discourse. $^{2}$ The micro-level impact of immigrants on natives' voting choices is a priori ambiguous ${ }^{3}$ and thus requires an empirical examination. This study focuses on Finland, a country that had a single far-right party (the Finns Party) for nearly 25 years (1995-2017) but was long considered immune to the surge of the far-right seen in other European countries (Ellinas 2010; Goodwin 2008; Ignazi 2003). The period of study is 2006 to 2015 . These years are characterized by both the historically largest inflow of foreign citizens into Finland (Koivukangas 2003) and a remarkable rise in the Finns Party's popularity. Indeed, there is a positive correlation between immigration and far-right voting on the national level (see Section 3 for more details). The analysis employs a novel panel dataset that spans 7 election years and 297 municipalities (all of mainland Finland). All types of national elections (i.e., parliamentary, presidential, and European parliamentary) are considered.

The sudden and unprecedented increase in immigration into Finland that followed the 2004 EU enlargement also provides an excellent setup for identification.

\footnotetext{
${ }^{1}$ The term far-right (or far right) is used in Betz (2008), Davies (2008), Ellinas (2010), Goodwin (2008), and Roxburgh (2002). The label populist radical right is preferred by Arter (2010) and Mudde (2007). Still, others use the terms right-wing populist (Norocel 2016; Swank and Betz 2002) or even extreme right (Carter 2005; Ignazi 2003). These different labels generally refer to the same party family.

${ }^{2}$ As proposed by Hopkins (2010) in his politicized places hypothesis, the two channels likely interact with each other. For example, in communities that experience a rapid demographic change during the period of salient national immigration rhetoric, immigrants can quickly become targets of local political hostility.

${ }^{3}$ Group conflict theory (Sherif et al. 1961) and ethnic competition theory (Olzak 1992) suggest a positive effect, while the intergroup contact theory (Allport 1954) predicts the opposite. Economic theories of labor market competition and the welfare-state are less clear-cut; the predictions depend on the precise characteristics of immigrants and natives (Scheve and Slaughter 2001; Facchini and Mayda 2012; Dustmann and Preston 2007).
} 
The 2003 distributions of immigrants by continent of citizenship can be used to construct a "shift-share" instrument (Altonji and Card 1991; Orrenius and Zavodny 2015) to identify the effect of immigration on far-right voting. One thing that makes this instrument particularly convincing in this case is the change in immigrant composition that followed the 2004 enlargement. While the 1990s and early 2000s were characterized primarily by an influx of Ingrian Finns from the former Soviet Union and asylum seekers from countries such as Somalia and former Yugoslavia (Koivukangas 2003), the 2004 and the subsequent EU enlargements brought in mostly economic migrants from Central and Eastern Europe. This minimizes the concern that IV results could be driven by persistent trends in anti-immigrant or pro-immigrant attitudes across municipalities.

Using the shift-share instrument, I find an economically meaningful and statistically significant negative effect of municipal in-migration of foreigners on the Finns Party's vote share. The IV coefficient from the preferred specification suggests that 1 percentage point increase in the share of foreign citizens in a municipality $(68 \%$ of the mean) decreases the Finns Party's vote share by about 3.35 percentage points ( $28 \%$ of the mean). Placebo tests using pre-period data confirm the IV estimate is not driven by persistent trends at the municipality level. To further validate the IV design, I re-estimate the main specification using a shift-share instrument constructed with 1991 immigrant distributions. ${ }^{4}$ The resulting coefficient remains negative, statistically significant at 5\%, and slightly larger in magnitude than the original estimate. Additional robustness checks such as the first-difference estimation, the inclusion of lagged-immigrant share, the exclusion of potential outliers, and the estimation with larger geographical units confirm the main result.

Considering the effect of immigration on voting for other parties, I find that the strongly pro-immigration Green League and Swedish People's Party gain votes. Indeed, their positive coefficients roughly add up to the negative estimate for the Finns Party. These positive effects are also relatively large; a 1 percentage point increase in the foreign share increases the Green League's vote share by $23 \%$ and the Swedish People's Party's vote share by 57\% with respect to the sample means.

Exploring the potential mechanisms behind my main finding, I first show that local foreign in-migration increases voter turnout (3\% with respect to mean), potentially activating a larger pro-immigration base. Interestingly, the share of protest votes remains unaffected by immigrant inflows. In addition, heterogeneity analysis reveals that the negative effect of immigration on the Finns Party's vote share is only present in places with large initial exposure to immigrants. This finding provides some evidence in favor of Allport (1954)'s intergroup contact theory which suggests that a meaningful contact between natives and immigrants can effectively ameliorate natives' anti-immigrant attitudes. Finally, I also find some evidence consistent with the welfare-state channel. In particular, I show that immigration increases municipal per capita personal income tax revenue, while per capita spending on social services, health care services, and education remain unaffected (Facchini and Mayda 2012; 2009; Dustmann and Preston 2007).

\footnotetext{
${ }^{4}$ Before any major immigrant inflow into Finland occurred.
} 
My analysis contributes to the growing economics literature on the effects of immigration on voting for the far-right and other anti-immigrant parties in Europe (described in more detail in Section 2). ${ }^{5}$ Most studies find a positive effect (Halla et al. 2017; Barone et al. 2016; Becker and Fetzer 2016; Edo et al. 2019; Gerdes and Wadensjö 2008; Harmon 2018; Mendez and Cutillas 2014; Otto and Steinhardt 2014; Brunner and Kuhn 2018), while the negative relationship has only been documented in Steinmayr (2018), and to some extent also in Dustmann et al. (2019) and Levi et al. (2020).

This study is the first to show that an inflow of economic migrants can reduce support for the far-right across all types of national elections. By contrast, both Steinmayr (2018) and Dustmann et al. (2019) consider the exposure to refugees through refugee allocation schemes. In addition, Steinmayr (2018) evaluates the impact of a specific and relatively short-term event - the European refugee crisisand considers only the extensive margin of immigration. This paper, on the other hand, focuses on the intensive margin and the study period spans 10 years and involves three types of national elections. Regarding Dustmann et al. (2019), the negative effect is present only in a limited subsample analysis of the 5\% most urban Danish municipalities (i.e., 26 observations). By contrast, I find no effect heterogeneity with respect to initial population size-the negative effect is present in municipalities both above and below the median initial population size.

Second, this paper examines a broad set of electoral outcomes in a parliamentary democratic system, which before the emergence of the Finns Party was characterized by basic electoral stability and the implosion of the party system. The former refers to low volatility of electoral gains and losses while the latter describes a scenario in which all major parties become center parties capable of forming a coalition government with one another (Arter 2008). In this political setting, uniquely positioned to face the threat of a right-wing populist party, I consider the impact of immigration on voting for other parties and voter turnout, as well as the protest vote. A few previous studies have considered the impact of immigration on voter turnout. Barone et al. (2016) find a negative effect, while Steinmayr (2018) finds no effect. Dustmann et al. (2019) find a positive effect but only in municipal elections, whereas I find an increase in turnout in the context of national elections. As far as the protest vote is concerned, the only other paper that considers it is Barone et al. (2016). While they find an increase in the share of invalid ballots in response to immigrant inflow, I find no effect on the protest vote.

Third, Finland provides a unique setting in a number of other dimensions as well. Before the 2004 EU enlargement, Finland was a country with minimal immigrant inflow and a very low far-right popularity. Even after 2004, both the stock and the inflow of migrants remained relatively low compared to other EU countries

\footnotetext{
${ }^{5} \mathrm{~A}$ number of correlational studies in political science have also considered the relationship between immigration and voting for European far-right parties. Results are mixed: positive association is found in Golder (2003), Swank and Betz (2002), and Anderson (1996); while Dülmer and Klein (2005), Messina (2007), and Kitschelt and McGann (1995) estimate a negative relationship.
} 
(Eurostat 2020). In addition, the majority of immigrants have been from Europe, with a large number of economic migrants arriving from Central and Eastern Europe following the 2006 and 2007 labor market openings. Last but not least, Finland is also interesting as it is characterized by an extensive welfare state, highly educated and aging population, compressed wage distribution, and high union density, all of which have likely played an important role in shaping natives' attitudes towards immigration (Sarvimäki 2011; Koivukangas 2003).

Fourth, this paper is one of only a handful of studies providing evidence for the welfare-state channel as a possible mechanism through which immigration affects far-right voting. This is particularly appealing given that Finland is a country with a generous welfare system (managed primarily by municipalities), and thus, native concerns about immigrant "benefit tourism" are especially relevant in this context. Previous papers have focused mostly on labor market and compositional amenities (Halla et al. 2017; Barone et al. 2016; Becker and Fetzer 2016), cultural diversity (Barone et al. 2016), the intergroup contact theory (Steinmayr 2018), and other non-economic aspects (Otto and Steinhardt 2014). Otto and Steinhardt (2014) do consider welfare channel as well, but they provide only indirect evidence.

The paper is organized as follows: Section 2 surveys the findings in the previous literature. Section 3 discusses the background. In Section 4, I describe the data and identification strategy. Results are presented in Section 5. Section 6 discusses potential mechanisms. Section 7 concludes.

\section{Related literature}

Far-right parties across Europe have strong anti-immigration rhetoric at the core of their political platforms. This feature stems from their ideology of ethno-nationalism (or nativism), defined by Betz (2008) to be a "strong belief that different societies and cultures adopt entirely different values, which are neither inferior, nor superior, but essentially incompatible with each other." This ideology makes far-right parties both nationalistic and xenophobic, and in recent years also Islamophobic (Mudde 2007). In a recent report, Esipova et al. (2015) suggest that Europeans are the most negative in the world towards immigration, with $52 \%$ preferring lower immigration levels in their countries. Thus, to better understand the recent rise in the far-right in Europe, it is instrumental to study the role immigration plays in this process.

A growing number of recent papers in economics have explored this issue empirically, each focusing on a case of a specific European country. Halla et al. (2017) use a shift-share instrument to study the effect of immigrant inflow on voting for the Freedom Party of Austria (FPÖ). They find a positive effect which is driven by voters' fear of the adverse impact of immigration on local labor markets and compositional amenities. In an Italian setting, Barone et al. (2016) show that foreign municipal in-migration increases vote share of the anti-immigrant center-right coalition (which includes the far-right Northern League). Proposed mechanisms in this study include cultural diversity, competition in the labor market and for public 
services, and political competition. Studies have also found a positive effect in Germany (Otto and Steinhardt 2014), UK (Becker and Fetzer 2016), France (Edo et al. 2019), Denmark (Gerdes and Wadensjö 2008; Harmon 2018), Spain (Mendez and Cutillas 2014), and Switzerland (Brunner and Kuhn 2018).

In contrast with the previous studies, Dustmann et al. (2019) use a quasi-random allocation of refugees into municipalities to study the impact of immigration on voting in Denmark. Documenting a large effect heterogeneity, the authors find that in all but the most urban municipalities, refugee inflow increases vote share of both antiimmigrant and center-right parties, while the vote share of center-left parties declines. However, in most urban municipalities, refugee allocation actually decreases support for anti-immigrant parties. The negative effect has also been documented in Steinmayr (2018) who suggests that hosting refugees in Austrian municipalities dampened the overall positive trend in support for the Freedom Party (FPÖ), consistent with Allport (1954)'s intergroup contact theory. Interestingly, he also finds that a brief exposure to a large number of refugees passing through the municipalities actually increased FPÖ's vote share. Similarly, Levi et al. (2020), considering the dynamics of migration and the voting for Britain's far-right UKIP, show that immigrants increase far-right support only in the short-run, while in the long-run, it is the opposite.

The relationship between immigration and far-right popularity is undeniably tied to the underlying attitudes of natives towards immigrants and immigration policy. Two economic channels have been identified as potential determinants of these sentiments. In line with the labor market hypothesis, Mayda (2006) finds that skilled individuals are more (less) likely to be pro-immigration in countries where the relative skill composition (i.e., ratio of skilled to unskilled labor) of natives to immigrants is high (low). Scheve and Slaughter (2001) draw a similar conclusion suggesting that less-skilled workers are significantly more likely to prefer limitation of immigrant inflows into the country.

The second economic mechanism is the so-called welfare-state channel. Consistent with its predictions, Facchini and Mayda $(2012,2009)$ find that in countries where immigrants are unskilled, pro-immigration preferences are negatively correlated with income and positively correlated with skill. These relationships are reversed in economies characterized by skilled migration. In a similar analysis, Dustmann and Preston (2007) find welfare concerns to be a more important determinant of natives' attitudes towards immigrants than labor market concerns.

A number of studies have also emphasized the importance of non-economic mechanisms such as crime, xenophobia, and the cultural or national identities (Nunziata 2015; O'Rourke and Sinnott 2006; Mayda 2006), as well as the significance of social cohesion in general (Zimmermann 2019). In a cross-country analysis of OECD countries, Bauer et al. (2000) show that natives in countries receiving mostly refugees care primarily about social issues such as crime, while those in countries with a lot of economic migrants are more concerned about their labor market outcomes. Finally, immigrants can also affect natives' non-pecuniary working conditions (Giuntella et al. 2019) and general life satisfaction (Akay et al. 2014, 2017). Both of these factors likely play an important role in determining natives' sentiments as well. 


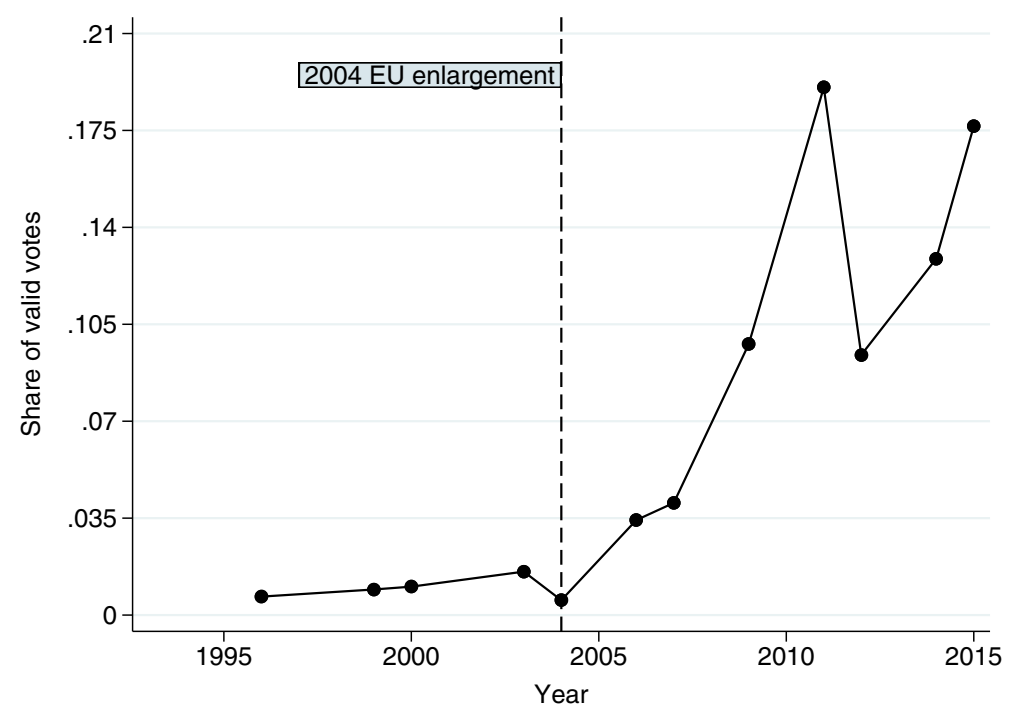

Fig. 1 Finns Party's vote share (all of Finland), 1996-2015. Notes - Data comes from Statistics Finland's StatFin database

\section{Background}

\subsection{The Finns Party}

The Finns Party (previously known as the True Finns; Finnish: Perussuomalaiset, PS) was the single far-right party in Finland since its establishment in 1995 until it split into two in mid-2017. In 1997, its first chairman, Raimo Vistbacka, was replaced by Timo Soini who led the party until 2017. Following a series of unsuccessful elections, the party made a breakthrough into the mainstream Finnish politics during the 2009 European election when it gained $9.79 \%$ of total votes (Fig. 1). In the 2015 parliamentary election, the Finns Party finished as a runner-up and for the first time formed a coalition government with the Centre Party and the National Coalition Party. Soini became the Minister of Foreign Affairs and the Deputy Prime Minister of Finland. In June 2017, following the election of new a chairman, Jussi Halla-aho, the party split into two: the Blue Reform remained in the coalition government while the Finns Party went into opposition. ${ }^{6}$ My study period (2006-2015) ends 2 years before the split occurred. The following description applies to the period of the Finns Party's uniform existence.

According to Norocel (2016), some Finnish scholars argue that the party is not necessarily a clear-cut case of far-right due to its strong left-leaning political agenda on economic matters. However, as Westinen (2014) points out, there is little doubt that the Finns Party is a nationalist-populist movement which combines ethno-nationalism and anti-elitism, typical features of far-right parties in Europe

\footnotetext{
${ }^{6}$ The Finns Party (official website): https://www.perussuomalaiset.fi/
} 
(Mudde 2007). ${ }^{7}$ This view is shared by Arter (2010) who claims that the notion of true Finnishness (suomalaisuus) is the pre-eminent concept of the Finns Party's ideology. Finally, Yla-Anttila and Yla-Anttila (2015) underline the points mentioned above suggesting that the Finns Party's ideology combines a populist defense of a common man against corrupt elites, a defense of welfare state against market-led policies, and a nationalist defense of the sovereignty and unity of the Finnish people against immigration and federalist tendencies of the European Union. These points clearly suggest that the Finns Party can be considered a member of the European far-right family.

The party has a strong anti-immigration platform, as described in the following statement from its 2015 parliamentary election campaign pamphlet:

"Immigration will change, irreversibly, the host country's population profile, disrupt social cohesion, overburden public services and economic resources, lead to the formation of ghettoes, promote religious radicalism and its consequences, and foster ethnic conflicts. [...] It can still be possible to avoid the immigration disasters of Sweden, France and the United Kingdom but it will require a determined policy and clear legislation." (source: The Finns Party's Immigration Policy, 2015)

Moreover, according to the Chapel Hill Expert Survey (CHES) data, which describes policy and ideological positions of national political parties in the EU, the Finns Party has been the sole anti-immigrant party in Finland since 2006. As Table 1 suggests, throughout the study period, the party was consistently in favor of a tough immigration policy while strongly opposing multiculturalism (advocating for immigrant assimilation instead). In addition, immigration policy was a very salient topic in Finns Party's manifestos (Table 1, column 4). Table 1 also reveals that none of the other main parties was anti-immigrant throughout the study period.

\subsection{Other political parties in Finland}

There are seven main political parties in Finland (other than the Finns Party): Social Democratic Party (SDP), Centre Party (Kesk), National Coalition Party (Kok), Green League (Vihr), Swedish People's Party (SFP/RKP), Christian Democrats (KD), and Left Alliance (vas.). The first three (SDP, Kesk, Kok), each founded over a century ago, have traditionally been the strongest parties regularly placing on top of the electoral lists. ${ }^{8}$ SDP is a moderate center-left social democratic party, while Kesk

\footnotetext{
${ }^{7}$ According to Mudde (2007), European far-right parties share three common ideological features: ethnonationalism, populism, and authoritarianism. Populism considers society to be ultimately separated into two groups, "the pure people" and "the corrupt elite," and argues that politics above all should be the expression of the will of the people. Authoritarianism is defined as a disposition to glorify, to be subservient to and remain uncritical towards authoritative figures of the ingroup (hence, the reason why far-right parties are typically led by authoritative leaders such as Le Pen, Wilders, and Soini).

${ }^{8}$ In recent years, before the 2017 split, the Finns Party briefly joined this "elite" club.
} 
Table 1 Immigration position and salience - main political parties in Finland (2006-2014)

\begin{tabular}{|c|c|c|c|c|}
\hline Party & Election year & Immig. policy position & Immig. policy salience & Multiculturalism \\
\hline \multirow[t]{3}{*}{ Finns Party } & 2006 & 8.11 & 8.22 & 7.89 \\
\hline & 2010 & 9.1 & 8.9 & 9.1 \\
\hline & 2014 & 9 & - & 9.38 \\
\hline \multirow[t]{3}{*}{ Vihr } & 2006 & 1.56 & 5.89 & 2.67 \\
\hline & 2010 & 2 & 7.1 & 2.1 \\
\hline & 2014 & 1.38 & - & 1.25 \\
\hline \multirow[t]{3}{*}{ SFP/RKP } & 2006 & 2 & 5.78 & 2.89 \\
\hline & 2010 & 2.2 & 6.7 & 2.4 \\
\hline & 2014 & 2.75 & - & 2.13 \\
\hline \multirow[t]{3}{*}{ Kok } & 2006 & 5 & 4.33 & 5.56 \\
\hline & 2010 & 5.8 & 4.5 & 5.5 \\
\hline & 2014 & 5.13 & - & 5.25 \\
\hline \multirow[t]{3}{*}{ Kesk } & 2006 & 5.67 & 3.89 & 5.67 \\
\hline & 2010 & 5.8 & 4.6 & 6.5 \\
\hline & 2014 & 5.63 & - & 6.25 \\
\hline \multirow[t]{3}{*}{ SDP } & 2006 & 4.78 & 3.78 & 5.11 \\
\hline & 2010 & 5.3 & 4.3 & 5.6 \\
\hline & 2014 & 4.13 & - & 4 \\
\hline \multirow[t]{3}{*}{$\mathrm{KD}$} & 2006 & 5.11 & 4.67 & 6 \\
\hline & 2010 & 6 & 5.56 & 6.89 \\
\hline & 2014 & 6.14 & - & 7.29 \\
\hline \multirow[t]{3}{*}{ vas. } & 2006 & 3.11 & 4.56 & 4 \\
\hline & 2010 & 3.7 & 4.9 & 4.3 \\
\hline & 2014 & 2.88 & - & 2.25 \\
\hline
\end{tabular}

Immig. policy position, position on immigration policy (0-10; 0 , "strongly opposes tough policy"; 10 , "strongly favors tough policy"). Immig. policy salience, importance/salience of immigration policy (0-10; 0, "not important at all"; 10, "extremely important"). Multiculturalism, position on integration of immigrants and asylum seekers (0-10; 0, "strongly favors multiculturalism"; 10, "strongly favors assimilation"). Vihr, Green League; SFP/RKP, Swedish People's Party; Kok, National Coalition Party; Kesk, Centre Party; $S D P$, Social Democratic Party; KD, Christian Democrats. Data comes from the 1999-2014 Chapel Hill Expert Survey (CHES) trend file

is centrist and Kok center-right, both of them having a liberal-conservative ideology (source: European Election Database). Although none of the seven parties was anti-immigrant during the study period, two of them-Green League and Swedish People's Party — did have strong pro-immigration platforms. Indeed, as Table 1 shows, between 2006 and 2014, Vihr and SFP/RKP had low scores on both Immigration policy position and Multiculturalism, indicating an opposition to tough immigration policy as well as a preference for multiculturalism. Moreover, as with the Finns Party, Vihr and SFP/RKP both considered immigration policy to be a very important topic in political discourse (Table 1, column 4). 


\subsection{National elections in Finland}

\subsubsection{Parliamentary elections}

Parliament of the Republic of Finland (Eduskunta) is unicameral, composed of 200 members directly elected by people for a 4-year term. Seats in the parliament are distributed among 13 electoral districts (or constituencies) in proportion to their populations 6 months prior to the election. This means that each constituency effectively holds its own parliamentary election. Candidates may be nominated by political parties or constituency associations (founded by at least 100 enfranchised persons from the same constituency). MPs are then chosen based on the number of votes they receive as well as the number of votes received by their party (or constituency association). Elections take place on the third Sunday in April, and voting can take place either in advance or on election day. ${ }^{9}$ Eligible to vote are all Finnish citizens aged 18 or above regardless of their domicile (Ministry of Justice 2010).

\subsubsection{Presidential elections}

The President of the Republic of Finland is elected in a direct vote for a 6-year term. Each presidential candidate must be a native-born Finnish citizen, and no individual can stay in the office for more than 2 consecutive terms. Candidates are nominated by parties that have currently at least 1 seat in the parliament, or by constituency associations established by at least 20,000 people entitled to vote. The election proceeds in one or two rounds, the second round being essentially a runoff between the two most successful candidates from the first round. The second round takes place only if no candidate gains more than $50 \%$ of all votes in round 1. Each presidential election is held on the fourth Sunday of January (round 1), with the second round taking place two weeks later. Voting eligibility is the same as in parliamentary elections; advance voting is also allowed (Ministry of Justice 2010).

\subsubsection{European elections}

As a member of the European Union, Finland can elect Members of the European Parliament (MEPs) who serve 5-year terms. The number of Finnish MEPs is determined by the ratio of the Finnish population to the population of the whole EU. ${ }^{10}$ Candidates for the European Parliament are nominated by political parties or constituency associations (established by at least 2,000 people), and voting proceeds as in the parliamentary elections. In contrast with parliamentary elections though, each

\footnotetext{
${ }^{9}$ An exception was the 2007 parliamentary election which was held on March 18 due to the 100th anniversary of the first Finnish parliamentary election (March 15-16, 1907).

${ }^{10}$ Finland has had 13 MEPs since 2009. Before that, there were 14 (1999-2009) and 16 MEPs (19961999), respectively.
} 


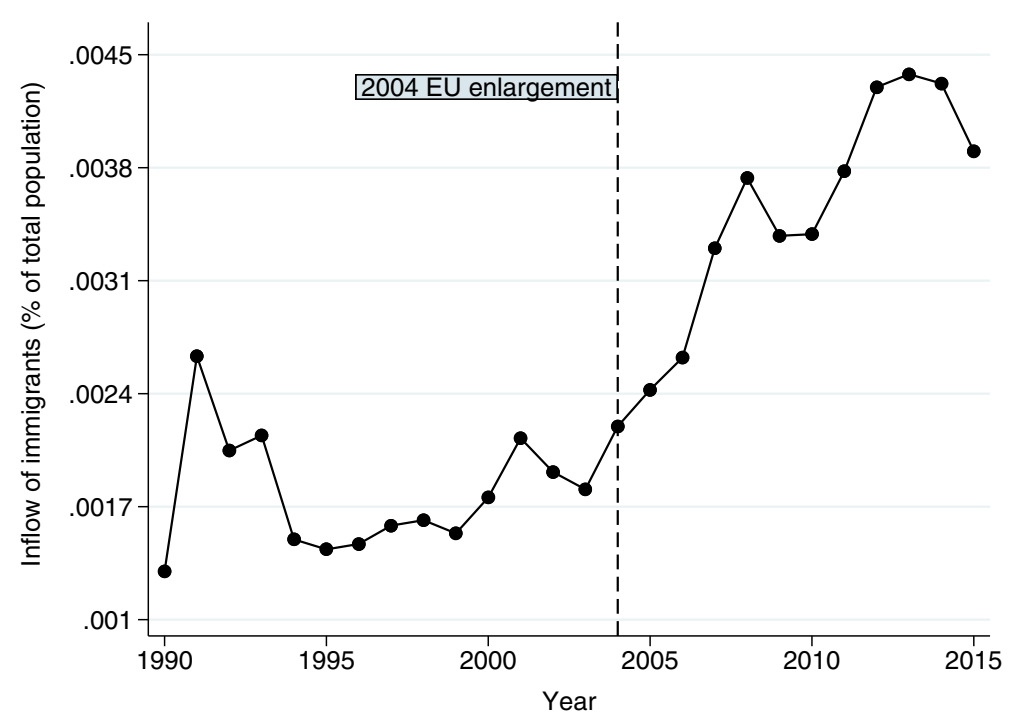

Fig. 2 Annual inflow of foreign citizens into Finland, 1990-2015. Notes - Data comes from Statistics Finland's StatFin database. Total population is measured at the beginning of the calendar year

candidate for an MEP enters the European election for the entire country. The election day is generally the second Sunday in June (Ministry of Justice 2010). ${ }^{11}$

\subsection{Immigration into Finland}

Historically, Finland has been characterized by emigration (Sarvimäki 2011). From the end of World War II until the early 1970s, the country attracted very few migrants. Although immigration increased in the 1970s, throughout the 1970s and 1980s some $85 \%$ of immigrants were return migrants coming mostly from Sweden. A small number of refugees from Vietnam and Chile also arrived during this period (Triandafyllidou and Gropas 2008). It was not until the 1990s that Finland experienced a major inflow of foreign citizens (Koivukangas 2003). As Fig. 2 suggests, the first significant wave of foreigners began arriving in 1991 and was caused by the dissolution of the Soviet Union and the civil wars in the (former) Yugoslavia and Somalia. Ingrian Finns from Russia and Estonia and asylum seekers from Yugoslavia and Somalia made up the largest foreign immigrant groups in Finland throughout the 1990s (Koivukangas 2003). Due (in part) to a restrictive refugee policy, ${ }^{12}$ the fraction of the population with foreign citizenship remained below $2 \%$ until 2003, one of the lowest in the EU during this period (Fig. 3; Koivukanga 2003).

\footnotetext{
${ }^{11}$ Although there are exceptions: the 1996 election was held on October 20 while the 2014 election took place on May 25.

${ }^{12}$ The annual refugee quota was 500 throughout the 1990s. In 2001, the quota was raised by the Finnish Parliament to 750. In recent years, due to an ongoing civil war in Syria, Finland has admitted more than a thousand quota refugees per year (source: Finnish Immigration Service).
} 


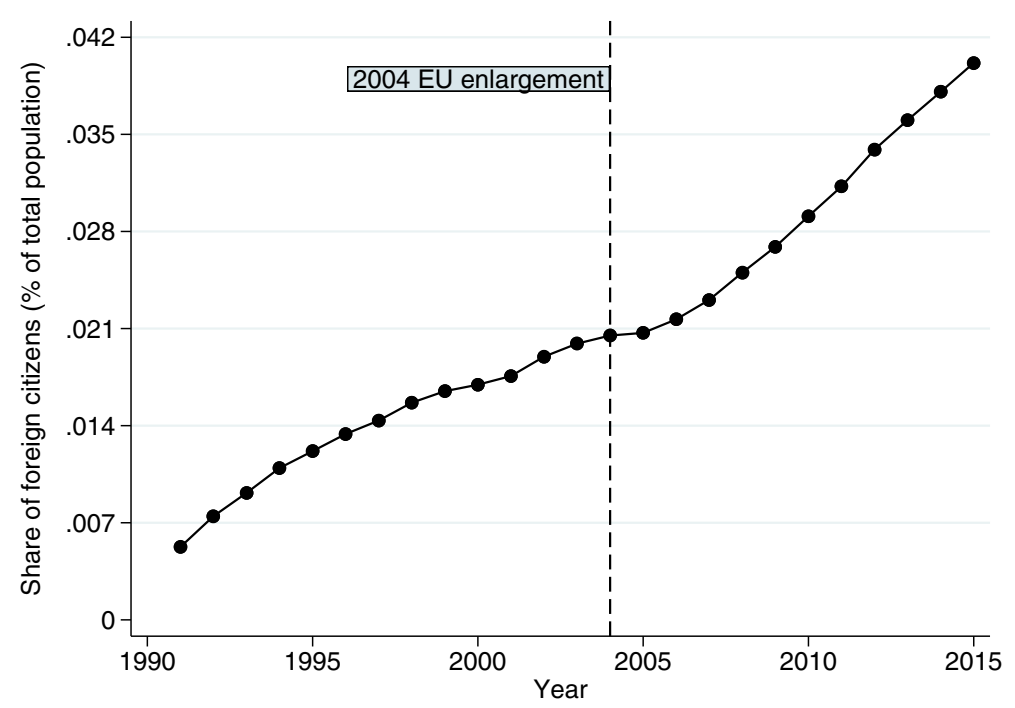

Fig. 3 Share of foreign citizens in Finland, 1991-2015. Notes - Data comes from Statistics Finland's StatFin database. Share of foreign citizens is measured at the beginning of the calendar year

As Fig. 2 depicts, the migration flow of foreign nationals into Finland increased dramatically in the late 2000s. In May 2004, the European Union accepted ten new member states (EU8 plus Malta and Cyprus). ${ }^{13}$ This historic enlargement was followed by the accession of Bulgaria and Romania (January 2007), and later Croatia (July 2013). Due to fears of mass migration of workers induced by the large economic disparities between East and West, EU member states agreed upon the so-called transitional restrictions. These restrictions allowed each old member to postpone the opening of its labor market to the new members for a period of up to 7 years. Finland opened its labor market to Malta and Cyprus immediately in 2004 but chose to wait until May 2006 for all EU8 countries. For Bulgaria, Romania, and Croatia, the workrelated immigration restrictions were lifted immediately upon their EU accession in January 2007 and July 2013, respectively (Pytliková 2014). Thus, while the 2004 enlargement already induced some inflow of foreigners (such as students) from Central and Eastern Europe, the two main immigration-inducing shocks were the 2006 and 2007 labor market openings. The period 2006 onwards is indeed the time of the largest immigrant inflow in Finnish history, and therefore, it is the focus of this study (see Fig. 2; Koivukangas 2003). As Fig. 4 confirms, the majority of incoming foreigners during this time were European citizens, primarily economic migrants from the new EU member states in Central and Eastern Europe (Fig. 5). Although, interestingly, the post-2006 period also saw a sizable increase in the inflow of non-European migrants (see Figures A.1 and A.2 in Appendix C, available in the GLO Discussion Paper, No. 540).

\footnotetext{
${ }^{13}$ EU8 refers to the following countries: Czech Republic, Poland, Hungary, Slovenia, Slovakia, Estonia, Latvia, and Lithuania.
} 


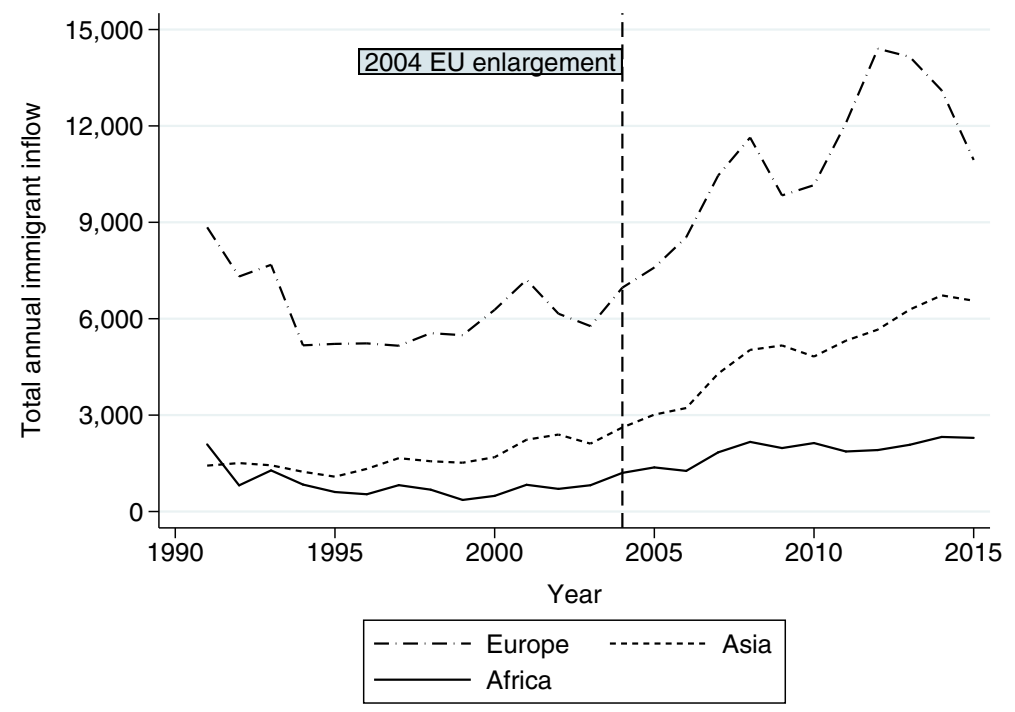

Fig. 4 Immigration into Finland (by group), 1991-2015. Notes - Data comes from Statistics Finland's StatFin database. Immigrants are divided according to their country of citizenship

In the last couple of years, Finland has also witnessed a sizable inflow of asylum seekers from Northern Africa and Middle East. However, since the last national election in Finland took place in mid-2015, my study period ends at the onset of the recent European refugee crisis, before any significant number of asylum seekers arrived in Finland.

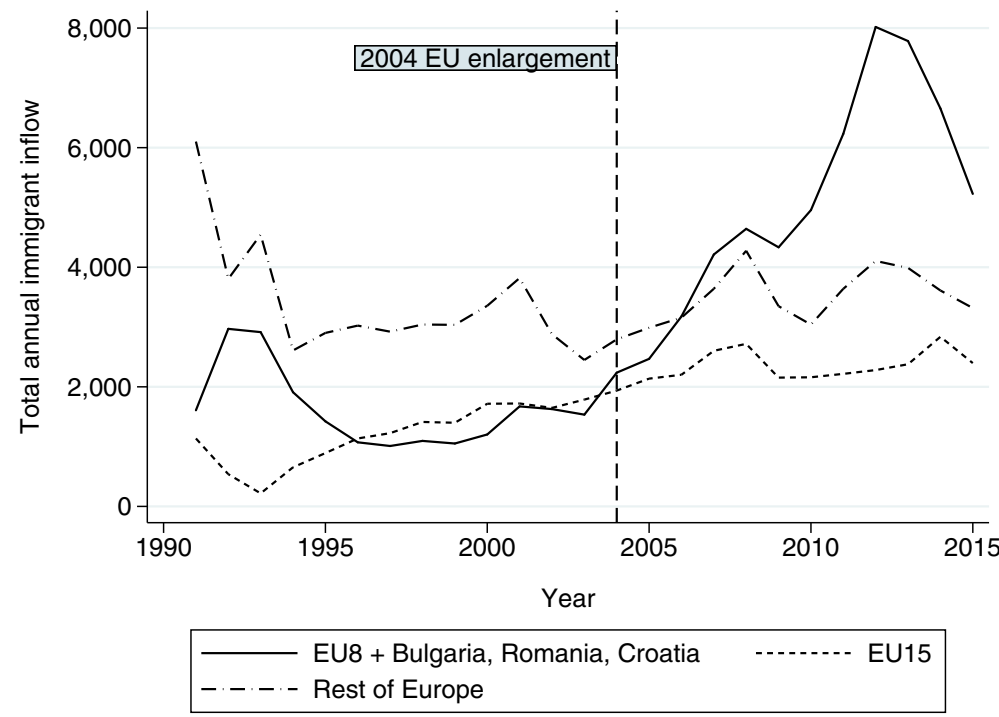

Fig. 5 European immigration into Finland (by group), 1991-2015. Notes - Data comes from Statistics Finland's StatFin database. Immigrants are divided according to their country of citizenship 


\section{Data and empirical strategy}

\subsection{Data}

The empirical analysis uses a municipality-by-election year panel dataset with 7 election years (2006-2015) and 297 municipalities. The following elections are used in the study: 2007, 2011, 2015 parliamentary elections; 2006, 2012 presidential elections (first round only); 2009, 2014 European elections. The Finns Party's candidate in both presidential elections was its leader, Timo Soini, who was eliminated in the first round in both cases. Municipal elections are not used in the analysis since any foreigner with a permanent residency in a given municipality is eligible to vote in that municipality's local election. ${ }^{14}$ A similar concern arises with European elections since non-Finnish EU citizens with a municipality of residence in Finland are eligible to vote for Finnish MEPs (Ministry of Justice 2010). Figure 6 plots the distribution of the share of votes cast by non-Finnish EU citizens across all municipalities in the 2014 European election. The histogram shows that almost $35 \%$ of municipalities had no foreigners casting a vote. ${ }^{15}$ Moreover, almost all municipalities are located below the $0.5 \%$ mark meaning the proportion of foreign votes cast in most cases was negligible. Histogram generated for the 2009 European election (available upon request) shows distribution that is even more skewed to the right. Nevertheless, as an additional robustness check, I exclude the 2009 and 2014 European elections from the analysis.

Spatially, the analysis extends to all of mainland Finland; excluded are only the Åland Islands (16 municipalities). Åland is a Swedish-speaking autonomous region that belongs to Finland and is located between continental Finland and Sweden. Its population makes up roughly $0.5 \%$ of the country's total population (sources: Statistics Finland, Statistics and Research Åland). Although the region has its own parliament, the people of Åland also elect one member of the Finnish Parliament in every national parliamentary election. However, the Islands have their own political parties and so voting for the Finns Party is not an option. Moreover, since the region is not only linguistically but also culturally Swedish, it would not be appropriate to include these municipalities in the same analysis with the rest of the country. ${ }^{16}$

In the past 12 years, the number of municipalities in Finland has been steadily shrinking to 313 (as of January 1, 2016). Municipality changes were mostly merges of two (or more) municipalities together. Information on all changes was provided by The Association of Finnish Local and Regional Authorities as well as Statistics Finland. The panel dataset is constructed using the 2016 municipality format. The dependent variable in the analysis is the Finns Party's share of valid votes. The independent variable of interest is the share of foreign citizens in a municipality. The analysis also includes the following municipality-specific time-varying controls that likely affect voting for the Finns Party: log of total population, popu-

\footnotetext{
${ }^{14}$ Data on the number of foreign votes cast in local elections (overall and for individual parties) is not available.

${ }^{15} 102$ out of 297 municipalities (34.3\%) had exactly 0 foreign votes in 2014 European election.

${ }^{16}$ The Office of Åland website: http://www.aland.ax/en/facts-about-aland/.
} 


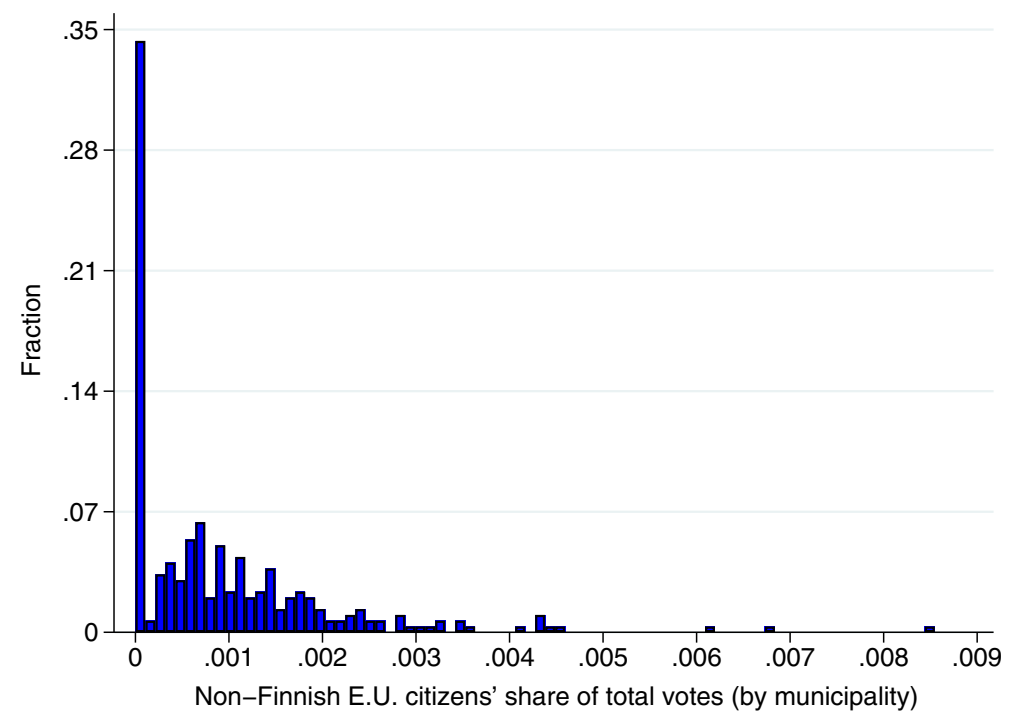

Fig. 6 Distribution of share of votes by other EU citizens, 2014 European election. Notes - Data comes from Statistics Finland's StatFin database

lation density $\left(\right.$ per $\mathrm{km}^{2}$ ), share of females in adult population, share of population (aged 25-64) with tertiary education, share of aged 65+ in adult population, ratio of skilled to unskilled labor (in population aged 20-64), total crime rate (per 100,000 population), unemployment rate, and median household disposable income (per consumption unit). More details about the covariates are reported in Appendix A. All data comes from Statistics Finland's public-use StatFin database. Table 2 provides the descriptive statistics for all variables.

A potential pitfall with using election vote share is naturalization, a process through which most foreigners without family ties to Finnish citizens obtain Finnish citizenship. Since naturalized Finns are de facto foreigners, a significant number of votes from these individuals will contaminate the dependent variable. However, as Gozdecka (2013) points out, Finnish citizenship has been a rather exclusive good aimed at foreign nationals who have put substantial effort into finding employment in Finland, learning Finnish language, and integrating themselves into Finnish society. This is indeed reflected in Finland's naturalization rate, ${ }^{17}$ which has had a fairly stable trend in the past 25 years (Fig. 7). During the 2006-2015 period, the naturalization rate had a declining trend (albeit with a considerable year-to-year variation). On average, the yearly rate was $3.6 \%$ during this time. Thus, although the problem with naturalization cannot be completely ruled out, the evidence presented here suggests that the number of naturalized Finns is not high enough to alter the results.

\footnotetext{
${ }^{17}$ Defined as the number of citizenships granted divided by the total foreign-born population.
} 
Table 2 Descriptive statistics

\begin{tabular}{|c|c|c|c|c|}
\hline & Mean & $\begin{array}{l}\text { Standard } \\
\text { deviation }\end{array}$ & Min & Max \\
\hline Finns Party's vote share & 0.120 & 0.076 & 0.001 & 0.534 \\
\hline Share of foreign citizens (\% of population in 1991) & 0.014 & 0.014 & 0.000 & 0.142 \\
\hline Population & $17,895.13$ & $44,697.37$ & 763 & 612,664 \\
\hline Population density (per km²) & 56.93 & 222.74 & 0.17 & $3,051.04$ \\
\hline Share of females in adult population & 0.499 & 0.014 & 0.438 & 0.543 \\
\hline Share of population (25-64) with tertiary education & 0.272 & 0.075 & 0.118 & 0.694 \\
\hline Share of aged $65+$ in adult population & 0.264 & 0.056 & 0.113 & 0.460 \\
\hline Ratio of skilled to unskilled labor & 3.44 & 1.10 & 1.35 & 8.93 \\
\hline Total crime rate (per 100,000 ) & $5,633.45$ & $3,130.57$ & $1,071.26$ & $63,930.13$ \\
\hline Unemployment rate & 0.119 & 0.043 & 0.028 & 0.288 \\
\hline Median household disposable income (EUR) & $20,572.79$ & $2,538.48$ & 14,765 & 36,799 \\
\hline
\end{tabular}

Number of observations: 2,079. Data comes from Statistics Finland's StatFin database

\subsection{Baseline fixed effects specification}

The baseline empirical specification is the fixed effects model of the form:

$$
\text { Far-right }_{i, t}=\alpha+\beta \text { Foreign }_{i, t}+X_{i, t}^{\prime} \gamma+\lambda_{t}+\mu_{i}+\epsilon_{i, t}
$$

where Far-right $_{i, t}$ is the Finns Party's share of valid votes in municipality $i$ and election year $t$. All elections used in the estimation take place in the first half of the

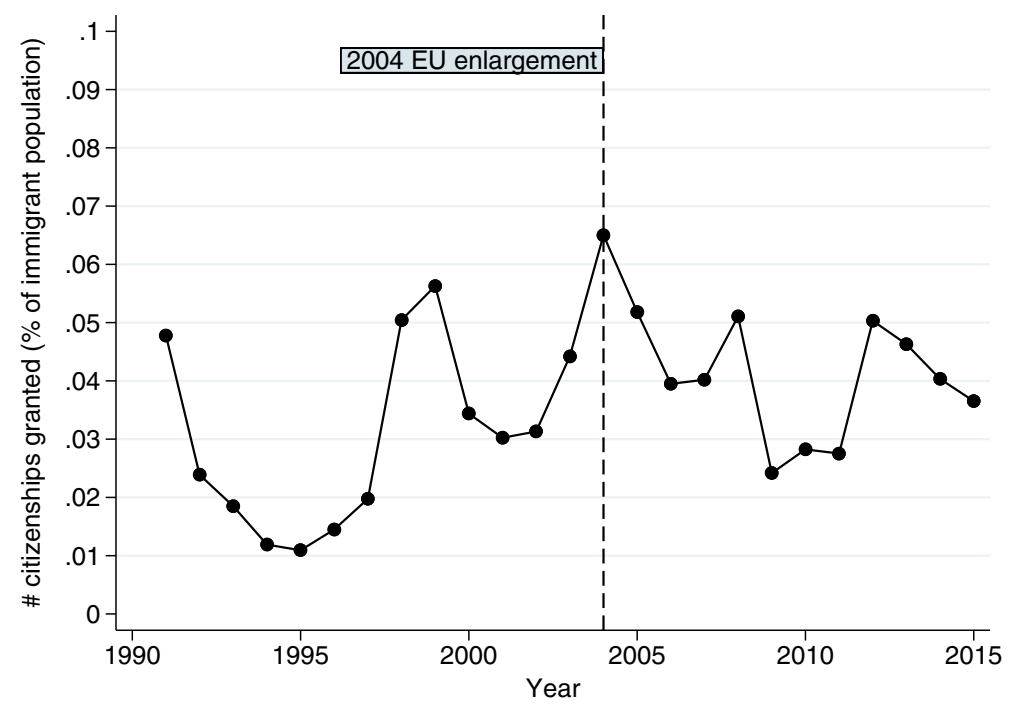

Fig. 7 Naturalization rate in Finland, 1991-2015. Notes - Data comes from Statistics Finland's StatFin database 
year. The independent variable of interest, Foreign $n_{i, t}=\left(\frac{\text { \# of Foreign Citizens }_{i, t}}{\text { Population }_{i, 2003}}\right)$, is the share of foreign citizens (as percentage of population in 2003) in municipality $i$ and election year $t$. The foreign share is measured on the first day of the calendar year. As commonly done in immigration literature, I standardize the number of foreigners by the population in the base year of the IV (discussed later). Population at $t$ is not used since it is likely endogenous to immigration. $X_{i, t}$ represents the set of municipality-specific time-varying controls mentioned earlier. Since covariate values at time $t$ are potential mechanisms through which immigration affects far-right vote share, I include them as 1 calendar year lags instead. The main specification also includes a full set of municipality fixed effects $\left(\mu_{i}\right)$ to capture municipalityspecific time-invariant determinants of Finns Party's vote share, and election year fixed effects $\left(\lambda_{t}\right)$ to control for year-specific shocks that equally affect all municipalities (e.g., 2009 Eurozone sovereign debt crisis). Finally, the preferred specification also includes region-by-election year fixed effects to control for local business cycles and other year-specific shocks that affect equally all municipalities within the same administrative region. The fixed effects specification has been used extensively in the immigration literature (e.g., Orrenius and Zavodny (2015), Giuntella et al. (2019), Barone et al. (2016), Giuntella et al. (2018)). However, as a robustness check, I estimate an alternative first-difference model, following the strategy proposed by Sá (2014).

The OLS estimation of Eq. 1 will likely suffer from endogeneity issues arising from sorting among both natives and immigrants. First, immigrants may decide to avoid anti-immigrant far-right strongholds. This has been shown in a recent paper by Slotwinski and Stutzer (2019) to be the case in Switzerland after its anti-minaret referendum in 2009. Following the specification suggested in Halla et al. (2017), I directly test for this reverse causality by regressing the change in the 2006-2015 immigrant share on a number of initial conditions including the 2003 Finns Party vote share. Results of this OLS estimation are presented in Table 3. Reassuringly, the municipalities with significant initial far-right support do not appear to be receiving less migrants after the 2004 EU enlargement. However, even if immigrants do not sort based on the pre-existing anti-immigrant sentiments, they might decide to leave municipalities which turn hostile towards them. This reverse causality would bias OLS downwards.

The second potential source of endogeneity is immigrant-induced native sorting. More specifically, an inflow of immigrants into a municipality may trigger an outflow of natives who face direct labor market competition (Borjas 2006). Also, as immigrants move in, natives who are anti-immigrant for non-economic reasons may decide to leave. A disproportionate number of natives who leave might therefore consist of far-right voters, in which case the OLS estimate will be biased downwards. On the other hand, pro-immigrant natives who derive positive utility from living in a diverse community could decide to move in together with the immigrants. Such inflow of natives who arguably do not support the Finns Party would bias the OLS estimate downwards as well.

Finally, as Borjas et al. (1996) suggest, immigrants may also cluster in areas with better socioeconomic conditions which are less supportive of the far-right, resulting 


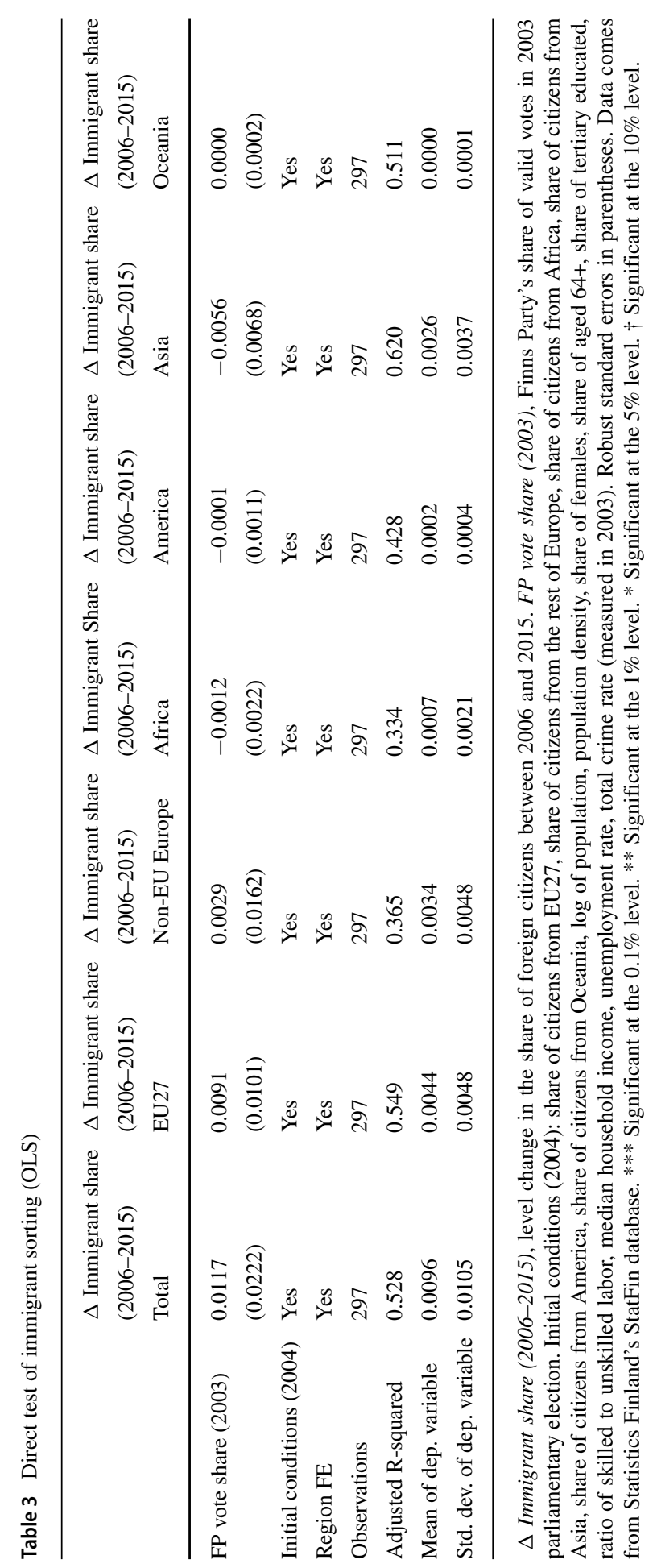


in a downward bias as well. On the other hand, as Halla et al. (2017) point out, if a community is hit by a negative economic shock which depresses housing prices, it may actually attract immigrants. If this shock also shifts voters' preferences to the far right, the resulting bias will be positive.

\subsection{Identification}

To identify the causal effect of interest, I employ an instrumental variable approach using a "shift-share" IV (Altonji and Card 1991). This instrument is based on an observation that immigrants tend to cluster in ethnic enclaves set up decades ago. My analysis uses a version of the instrument proposed by Orrenius and Zavodny (2015). More specifically, I first determine the distribution of foreigners by continent of citizenship across mainland Finnish municipalities in 2003 (base year). Then, for

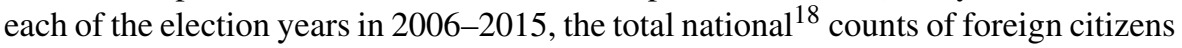
are distributed according to the 2003 distributions. The instrument has the form:

$$
\widehat{\text { Foreign }}_{i, t}=\frac{\sum_{j=1}^{6} \text { Foreign }_{t}^{j} * \text { Share in } \mathrm{i}_{2003}^{j}}{\text { Population }_{i, 2003}}
$$

${ }_{\text {where Foreign }}{ }_{i, t}$ is the predicted share of foreign citizens in municipality $i$ in election year $t$, Foreign ${ }_{t}^{j}$ is the number of foreign citizens from continent $j$ in mainland Finland in election year $t$, and Share in $\mathrm{i}_{2003}^{j}$ is the share of foreigners with continent of citizenship $j$ in municipality $i$ in 2003. As the summation indicates, immigrants are divided into 6 groups based on their citizenship (each group roughly corresponds to a continent): EU27 Europe, ${ }^{19}$ non-EU Europe, Africa, Asia, America (North, Central, and South America combined), and Oceania. Figures A.3 and A.4 (in Appendix C available in the GLO Discussion Paper, No. 540) show the 2003 spatial distribution for each of these groups.

For the instrument to be valid, the predicted share of foreigners can affect the Finns Party vote share only through its direct effect on the actual share of foreigners. 2003 is chosen as the base year because it precedes the 2004 EU enlargement and the subsequent inflow of Central and Eastern European migrants. Moreover, it marks a change in the composition of immigrants coming into Finland (from asylum seekers to economic migrants). Thus, conditional on covariates and fixed effects, the 2003 distributions are unlikely to be correlated with unobservable predictors of anti-immigrant attitudes and Finns Party popularity after 2006. As an additional robustness check, the IV analysis is re-estimated using 1991 as the base year (15 years before my study period). Since immigration of foreigners into Finland was minimal before 1991, the results from this alternative IV estimation serve as further evidence validating the exclusion restriction of the original instrument.

The IV estimates could still be invalid if there is a persistence of municipalityspecific trends in pro-immigrant and/or anti-immigrant attitudes. The inclusion of the

\footnotetext{
${ }^{18}$ The term "national" refers to mainland Finland.

${ }^{19}$ This definition includes all 27 current members of the European Union (excluding Finland).
} 
region-by-election year fixed effects mitigates this concern. In addition, I conduct placebo tests with pre-period election data (1995-2003) to directly test for such persistence. Finally, if natives "vote with their feet" and if this native sorting after 2006 is correlated with the baseline immigrant distributions, IV estimate will be biased. I therefore re-estimate Eq. 1 using the same IV approach, but larger geographical units (administrative subregions and regions). A significant change in the IV coefficient will indicate the presence of such bias. In addition, I conduct a direct test of native sorting using an approach proposed in Peri and Sparber (2011).

\section{Results}

\subsection{Main results}

Before showing the regression estimates, it is useful to first consider visual evidence. In Fig. 8, I map the spatial distribution of Finns Party's average 2006-2015 vote share as well as the distribution of the average 2006-2015 immigrant share. The figure
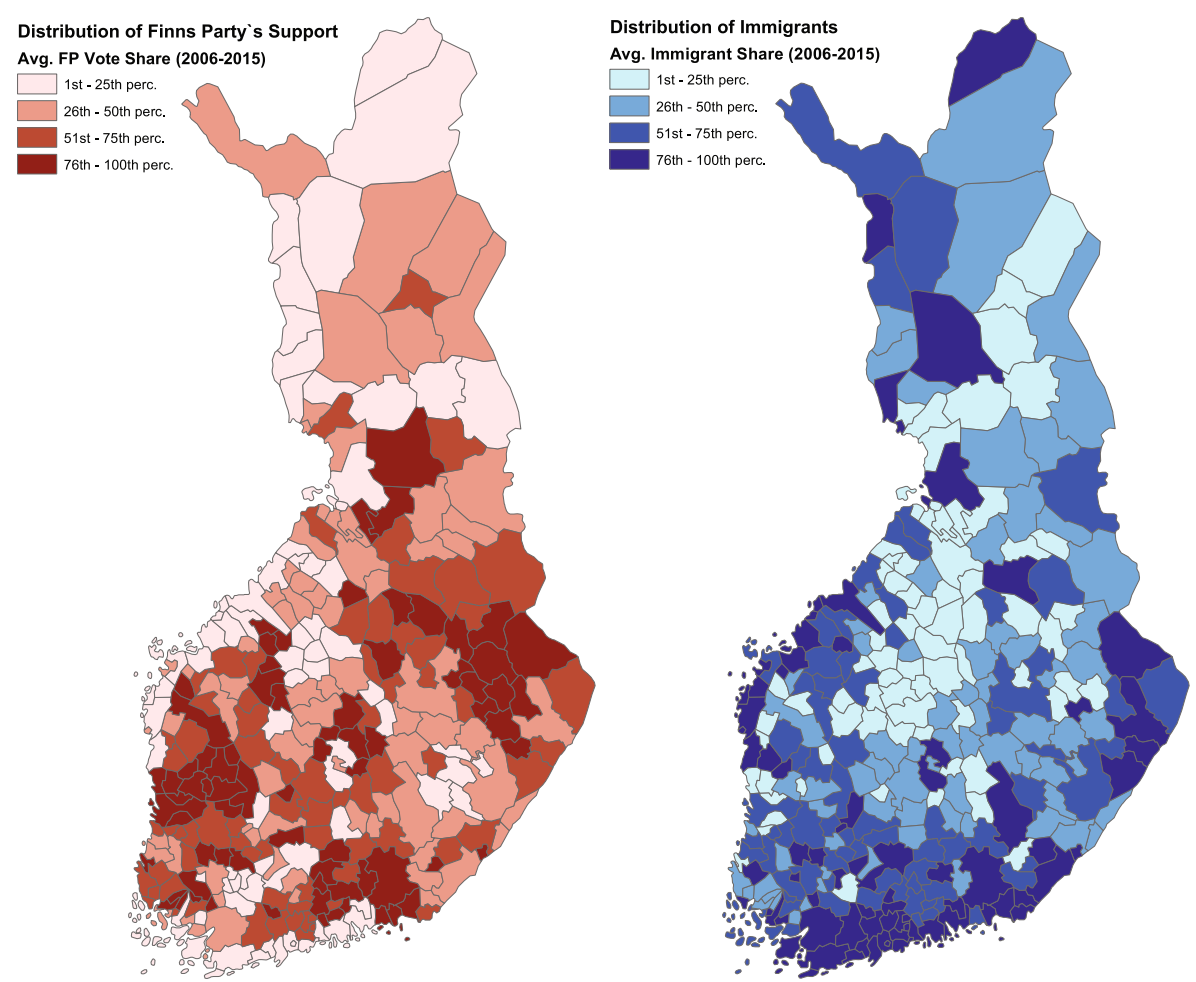

Fig. 8 Average Finns Party vote share vs. share of foreign citizens (2006-2015). Notes - Data comes from Statistics Finland's StatFin database. 2016 municipality-level ArcGIS shapefile was provided by The Association of Finnish Local and Regional Authorities. Both maps depict all of mainland Finland (297 municipalities in total) and employ a Transverse Mercator projection. The 16 Swedish-speaking municipalities of Åland Islands are excluded 
suggests a negative relationship between immigration and far-right voting on a local level. In particular, the coastal municipalities in southern Finland (around the cities of Helsinki, Espoo, and Turku) have large immigrant shares but low support for the Finns Party. Similar pattern holds for a number of municipalities on the west-central coast (around the cities of Oulu, Kokkola, and Vaasa) as well as some municipalities in the northernmost region of Lapland. On the other hand, many of the landlocked municipalities in south-central Finland display a substantial support for the far-right party but a low concentration of immigrants.

Table 4 presents main regression results from the estimation of Eq. 1 using OLS (cols. 1-3) and IV (cols. 4-6) methods. The coefficient of interest is negative and remains significant at $5 \%$ in all specifications. The OLS estimates are fairly small in magnitude (5-11\% with respect to the sample mean). The IV coefficients are roughly 2-5 times larger than OLS depending on the specification. First-stage results (Table 12) confirm the instrument is strong; the Kleibergen-Paap rk Wald F-statistic (22.77) exceeds the Stock-Yogo 10\% maximum IV size critical value even in the full specification (col. 3). The IV coefficient from the preferred specification (Table 4, col. 6) suggests that a 1 percentage point increase in the share of foreigners in a municipality (68\% of the mean) decreases Finns Party's electoral support by about 3.35 percentage points ( $28 \%$ of the mean). Put differently, 1 standard deviation increase in the foreign share decreases Finns Party's vote

Table 4 Main results

\begin{tabular}{|c|c|c|c|c|c|c|}
\hline & (OLS) & (OLS) & (OLS) & (IV) & (IV) & (IV) \\
\hline & Finns Party & Finns Party & Finns Party & Finns Party & Finns Party & Finns Party \\
\hline Share of foreign citizens & $-0.659 *$ & $-1.284 * * *$ & $-0.656^{*}$ & $-1.464 * * *$ & $-4.103 * * *$ & $-3.351 * * *$ \\
\hline (\% of population in 2003 ) & $(0.300)$ & $(0.341)$ & $(0.303)$ & $(0.373)$ & $(0.809)$ & $(0.936)$ \\
\hline $\begin{array}{l}\text { Municipality/election } \\
\text { year FE }\end{array}$ & Yes & Yes & Yes & Yes & Yes & Yes \\
\hline Time-varying controls (lag) & & Yes & Yes & & Yes & Yes \\
\hline $\begin{array}{l}\text { Region FE } \times \text { election } \\
\text { year FE }\end{array}$ & & & Yes & & & Yes \\
\hline Observations & 2,079 & 2,079 & 2,079 & 2,079 & 2,079 & 2,079 \\
\hline Adjusted R-squared & 0.832 & 0.836 & 0.880 & - & - & - \\
\hline Mean of dep. variable & $12 \%$ & $12 \%$ & $12 \%$ & $12 \%$ & $12 \%$ & $12 \%$ \\
\hline Std. dev. of dep. variable & $7.56 \%$ & $7.56 \%$ & $7.56 \%$ & $7.56 \%$ & $7.56 \%$ & $7.56 \%$ \\
\hline $\begin{array}{l}\text { Kleibergen-Paap rk } \\
\text { Wald F-stat. }\end{array}$ & - & - & - & 62.32 & 34.53 & 22.77 \\
\hline
\end{tabular}

Finns Party, Finns Party's share of valid votes. Standard errors in parentheses, clustered at municipality level. Based on slope estimate in the last column, 1 std. dev. increase in share of foreign citizens decreases FP vote share by 4.36 p.p. (58\% of its std. deviation). Time-varying controls: log of population, population density, share of females, share of tertiary educated, share of aged $65+$, ratio of skilled to unskilled labor, total crime rate, unemployment rate, median household income. Data comes from Statistics Finland's StatFin database. $* * *$ Significant at the $0.1 \%$ level. ** Significant at the $1 \%$ level. * Significant at the $5 \%$ level. $\dagger$ Significant at the $10 \%$ level. 
share by 0.58 standard deviations. The large magnitude implies an economically important effect.

For comparison, Steinmayr (2018) suggests that hosting refugees in a municipality decreases far-right FPÖ's vote share by 4.42 percentage points. This magnitude is (in absolute terms) very similar to mine, although the two estimates are clearly not directly comparable since I consider the intensive margin of immigration. Dustmann et al. (2019) in their paper find that in the top 5\% of urban Danish municipalities, 1 percentage point increase in the refugee share between electoral cycles decreases the vote share for anti-immigration parties by 3.79 percentage points in parliamentary elections. Given these parties' overall vote share of $7.6 \%$, this is indeed a similarly large effect. Lastly, Barone et al. (2016), finding a positive effect in Italy, show that 1 standard deviation increase in foreign share increases the vote share of the antiimmigrant center-right coalition (including the far-right Northern League) by 0.33 standard deviations. In relative terms, this effect is roughly half the size of my estimate.

The difference between my OLS and IV estimates is likely caused by attenuation bias arising from measurement error in the main independent variable. As Angrist and Pischke (2008) explain, if the measurement error is random, the OLS coefficient will be biased towards zero. An instrumental variable approach can correct for this bias. In the context of immigration, Aydemir and Borjas (2011) suggest that the attenuation bias arising from even a small measurement error can be significant if the model includes a large number of fixed effects. That is indeed the case here. Results in Sections 5.5 and 6.1 lend further credibility to the idea of attenuation bias. Using the same IV to estimate the effect of immigration on other electoral outcomes (e.g., voter turnout, other parties' vote shares), I find that in every specification, the OLS estimate is attenuated towards zero, regardless of the coefficient sign (see Sections 5.5 and 6.1 for more details).

To explore the likely source of this attenuation bias, I consider more closely the procedure implemented by Statistics Finland to account for the foreign citizens living in a municipality in a given year. First, foreign citizens are counted in only if they intend to live in Finland for at least 12 months upon arrival into the country. Thus, some students, workers, and other visitors are excluded, even though their presence might affect natives' voting preferences. Another important group that is not included in the measurement of the foreign population is asylum seekers whose applications are pending. On the other hand, foreign citizens with permanent residency in Finland are counted in the data even if they are temporarily living abroad, in which case my main independent variable will overcount the "true" immigrant population (Statistics Finland 2016).

\subsection{Alternative first-difference specification}

As the main robustness check, I estimate an alternative, first-difference version of Eq. 1 which uses net immigrant flow as the main independent variable. The specification is based on the main estimating equation in Sá (2014) and has the following form:

$$
\Delta \text { Far-right }_{i, t}=\beta\left(\frac{\Delta \text { Foreign-born }_{i, t}}{\text { Population }_{i, 2003}}\right)+X_{i, t-1}^{\prime} \gamma+\lambda_{t}+\sigma_{i}+\epsilon_{i, t}
$$


where $\Delta$ Far-right $_{i, t}$ is the level change in Finns Party's vote share in municipality $i$ between elections at $t-1$ and $t .^{20} \Delta$ Foreign-born $_{i, t}$ is the change in the number of foreign citizens in municipality $i$ between $t-1$ and $t$. To be consistent with Eq. 1, I standardize the change in the number of immigrants by population in the base year (2003). Covariates are included in lagged levels $\left(X_{i, t-1}\right)$ since the level changes between $t-1$ and $t$ are endogenous to immigration. Estimating a first-difference model means that the municipality-specific fixed effects are differenced out. Thus, $\sigma_{i}$ captures municipality-specific trends in Finns Party's vote share. Finally, $\lambda_{t}$ captures national trends in factors that affect far-right vote share, such as the trend in Finland's GDP per capita. To deal with endogeneity in $\beta$ (the coefficient of interest), I construct the following instrument which uses the same distributions of immigrants by continent of citizenship in 2003 as the instrument in my main analysis:

$$
\frac{\sum_{j=1}^{6} \delta_{i, j, 2003} * \Delta \text { Foreign-born }_{j, t}}{\text { Population }_{i, 2003}}
$$

where $\delta_{i, j, 2003}$ is the share of immigrants with continent of citizenship $j$ living in municipality $i$ in 2003. $\Delta$ Foreign-born $_{j, t}$ is the change in the overall number of foreign citizens from continent $j$ in mainland Finland between $t-1$ and $t$. Estimation results are presented in Table 5. In columns (4)-(6), I replicate the analysis with population at $t-1$ (instead of the population in 2003) in the denominator. Although the interpretation of $\beta$ in the first-difference case differs from that in my main specification, reassuringly, all estimates in Table 5 remain negative and statistically significant at $5 \%$.

\subsection{Robustness checks, placebo tests, and shift-share critique}

I conduct a battery of additional robustness checks to test the sensitivity of the IV estimates. Results are reported in Appendix B. Table 13 confirms that eliminating some of the potentially "bad" controls (such as unemployment rate or median household income) does not significantly alter the results. In addition, using 1991 (instead of 2003) as the base year for the instrument slightly increases the magnitude of the IV estimates, although the standard errors increase as well due to a weaker first stage (Table 14). The IV estimates are also robust to the exclusion of European elections (Table 15) as well as the exclusion of 9 largest municipalities as potential outliers (Table 16). Although the full specification (column 3) in both Table 14 and Table 16 exhibit a weak instrument problem, the weak-IV robust Anderson-Rubin chi-sq. pvalue confirms the 5\% level significance of both IV estimates. Finally, I re-estimate the model separately for each election type (parliamentary, presidential, European). The coefficient on immigrant share is negative, statistically significant, and with comparable magnitudes across the three specifications suggesting that the negative effect is not limited to a specific type of national election (Table 17).

\footnotetext{
${ }^{20}$ For those election years that are more than one calendar year apart, $t-1$ refers to the preceding election year and not the preceding calendar year.
} 
Table 5 Alternative first-difference specification (IV results)

\begin{tabular}{|c|c|c|c|c|c|c|}
\hline & $\begin{array}{l}(1) \\
\Delta \text { Finns } \\
\text { Party }\end{array}$ & $\begin{array}{l}(2) \\
\Delta \text { Finns } \\
\text { Party }\end{array}$ & $\begin{array}{l}(3) \\
\Delta \text { Finns } \\
\text { Party }\end{array}$ & $\begin{array}{l}(4) \\
\Delta \text { Finns } \\
\text { Party }\end{array}$ & $\begin{array}{l}(5) \\
\Delta \text { Finns } \\
\text { Party }\end{array}$ & $\begin{array}{l}(6) \\
\Delta \text { Finns } \\
\text { Party }\end{array}$ \\
\hline $\begin{array}{l}\text { Net immigrant flow } \\
\text { (\% of population in } 2003 \text { ) }\end{array}$ & $\begin{array}{l}-4.063^{*} \\
(1.975)\end{array}$ & $\begin{array}{l}-4.144 * \\
(1.978)\end{array}$ & $\begin{array}{l}-4.566^{*} \\
(2.059)\end{array}$ & & & \\
\hline $\begin{array}{l}\text { Net immigrant flow } \\
(\% \text { of population in } \mathrm{t}-1)\end{array}$ & & & & $\begin{array}{l}-4.736^{*} \\
(2.193)\end{array}$ & $\begin{array}{l}-4.780 * \\
(2.196)\end{array}$ & $\begin{array}{l}-5.269^{*} \\
(2.279)\end{array}$ \\
\hline Population density (1-year lag) & Yes & Yes & Yes & Yes & Yes & Yes \\
\hline Female share (1-year lag) & Yes & Yes & Yes & Yes & Yes & Yes \\
\hline Share aged $65+(1-$ year lag $)$ & Yes & Yes & Yes & Yes & Yes & Yes \\
\hline $\begin{array}{l}\text { Share tertiary educated } \\
(1-\text { year lag) }\end{array}$ & Yes & Yes & Yes & Yes & Yes & Yes \\
\hline Log of population (1-year lag) & Yes & Yes & Yes & Yes & Yes & Yes \\
\hline Skill ratio (1-year lag) & & Yes & Yes & & Yes & Yes \\
\hline Total crime rate (1-year lag) & & Yes & Yes & & Yes & Yes \\
\hline $\begin{array}{l}\text { Unemployment rate } \\
(1-\text { year lag) }\end{array}$ & & & Yes & & & Yes \\
\hline $\begin{array}{l}\text { Median household income } \\
\text { (1-year lag) }\end{array}$ & & & Yes & & & Yes \\
\hline Observations & 1,782 & 1,782 & 1,782 & 1,782 & 1,782 & 1,782 \\
\hline Mean of dep. variable & $2.55 \%$ & $2.55 \%$ & $2.55 \%$ & $2.55 \%$ & $2.55 \%$ & $2.55 \%$ \\
\hline Std. dev. of dep. variable & $7.52 \%$ & $7.52 \%$ & $7.52 \%$ & $7.52 \%$ & $7.52 \%$ & $7.52 \%$ \\
\hline Kleibergen-Paap rk Wald F-stat. & 53.61 & 53.71 & 53.52 & 45.69 & 45.82 & 45.88 \\
\hline
\end{tabular}

$\Delta$ Finns Party, level change in Finns Party's share of valid votes between elections at $t-1$ at $t$. Net immigrant flow, change in number of foreign citizens between election year $t-1$ and $t$. Standard errors in parentheses, clustered at municipality level. All regressions also control for municipality-specific time trends (municipality dummies), national trends (election year dummies). Data comes from Statistics Finland's StatFin database. *** Significant at the $0.1 \%$ level. ** Significant at the $1 \%$ level. * Significant at the $5 \%$ level. $\dagger$ Significant at the $10 \%$ level.

A natural concern with a shift-share instrument is that persistent trends at the municipality level may be correlated both with the IV and the outcome of interest. To partially address this endogeneity concern, I conduct a placebo test using pre-period election data. In particular, I estimate the following cross-sectional specification using OLS:

$$
\Delta \text { Far-right }_{i, 1999-2003}=\alpha+\beta \Delta \widehat{\text { Foreign }}_{i, 2006-2015}+\phi_{r}+\epsilon_{i}
$$

where $\Delta$ Far - right $_{i, 1999-2003}$ is the level change (or percentage change) in Finns Party's vote share in municipality $i$ between 1999 and 2003, and $\widehat{\Delta \text { Foreig }} n_{i, 2006-2015}$ is the level change (or percentage change) in the IV (using 2003 as baseline) in municipality $i$ between 2006 and 2015. The regression also controls for region fixed effects $\left(\phi_{r}\right)$ and a set of municipality-specific controls measured 
in 2003. Results of the placebo test are presented in Table 6 (cols. 1 and 3). Reassuringly, a lack of any statistically significant correlation supports the validity of the IV's exclusion restriction.

In columns (2) and (4) of Table 6, I repeat the same placebo analysis, but this time using the change in Centre Party's vote share between 1995 and 1999 as my dependent variable. According to Jaakkola (2000), during this period, voting for the Centre Party was associated with negative attitudes towards immigrants. The Centre Party placed as a runner-up in both the 1995 and the 1999 parliamentary elections, capturing $19.9 \%$ and $22.4 \%$ of votes, respectively. Reassuringly, the results from this placebo test (Table 6, cols. 2 and 4) suggest no statistically significant correlation between the 2006 and 2015 trend in the shift-share instrument and the 1995-1999 trend in the Centre Party's popularity, further strengthening the validity of my identification strategy.

The shift-share instrument itself has also been challenged in a recent paper by Jaeger et al. (2018), who argue that the estimate of the short-run effect of immigration could be "contaminated" by the long-run general equilibrium effect of previous immigrant wave(s). Thus, I follow their suggestion and include a 2-year lag of the share of foreign citizens in the main specification. Both the immigrant share and its lagged counterpart are instrumented for using the shift-share IV based on 2003 baseline distributions. Results are presented in Table 18. The main IV coefficient increases in magnitude while also remaining statistically significant at $0.1 \%$ level. Although the Kleibergen-Paap rk Wald F-stat. in the full specification (Table 18, col.

Table 6 Placebo test (OLS)

\begin{tabular}{lllll}
\hline & $\begin{array}{l}\Delta \text { Finns Party } \\
(1999-2003)\end{array}$ & $\begin{array}{l}\Delta \text { Kesk } \\
(1995-1999)\end{array}$ & $\begin{array}{l}\% \text { Finns Party } \\
(1999-2003)\end{array}$ & $\begin{array}{l}\% \Delta \text { Kesk } \\
(1995-1999)\end{array}$ \\
\hline$\Delta$ IV (2006-2015) & 0.106 & 0.902 & & -0.108 \\
$\% \Delta$ IV (2006-2015) & $(0.214)$ & $(0.658)$ & 0.620 & $(0.080)$ \\
Region FE & & & $(0.598)$ & Yes \\
Observations & Yes & Yes & Yes & 297 \\
Adjusted R-squared & 0.168 & 297 & 297 & 0.130 \\
Mean of dep. variable & -0.002 & 0.111 & 0.251 & 0.167 \\
\hline
\end{tabular}

$\Delta$ Finns Party (1999-2003), level change in Finns Party's share of valid votes between 1999 and 2003. \% $\Delta$ Finns Party (1999-2003), percentage change in Finns Party's share of valid votes between 1999 and 2003. $\Delta$ Kesk (1995-1999), level change in Centre Party's share of valid votes between 1995 and 1999. \% $\Delta$ Kesk (1995-1999), percentage change in Centre Party's share of valid votes between 1995 and 1999. $\Delta I V$ (2006-2015), level change in the predicted share of foreign citizens between 2006 and 2015. $\% \Delta I V$ (2006-2015), percentage change in the predicted share of foreign citizens between 2006 and 2015. Estimation also includes the following 2003 controls: log of population, population density, share of females, share of tertiary educated, share of aged 65+, ratio of skilled to unskilled labor, total crime rate, unemployment rate, median household income. Robust standard errors in parentheses. Data comes from Statistics Finland's StatFin database. *** Significant at the $0.1 \%$ level. ** Significant at the $1 \%$ level. * Significant at the 5\% level. $\dagger$ Significant at the $10 \%$ level. 
3) drops to 10.62, the weak instrument-robust Anderson-Rubin chi-sq. test confirms the statistical significance of the main estimate.

\subsection{Direct test of native sorting}

As noted earlier, another threat to identification comes from immigrant-induced native mobility. Different specifications have been suggested to test for it. ${ }^{21}$ Peri and Sparber (2011) evaluate each of these specifications using simulated data and find that some of them have built-in biases. They suggest estimating the following model which is based on Card (2009):

$$
\left(\frac{N_{i, t}-N_{i, t-1}}{\operatorname{Pop}_{i, t-1}}\right)=\alpha+\beta\left(\frac{F_{i, t}-F_{i, t-1}}{\operatorname{Pop}_{i, t-1}}\right)+\phi_{i}+\lambda_{t}+\epsilon_{i, t}
$$

where $N_{i, t}$ is the number of Finnish citizens in municipality $i$ and election year $t$, and $N_{i, t-1}$ is the number of Finnish citizens in $i$ in $t-1$ (i.e., 1 calendar year before $t$ ). Similarly, $F_{i, t}$ and $F_{i, t-1}$ refer to the number of foreign citizens in $i$ at $t$ and $t-1$, respectively. Pop $\operatorname{Pot}_{i-1}$ is the total population in municipality $i$ in $t-1$. The specification also controls for municipality fixed effects $\left(\phi_{i}\right)$ and election year fixed effects $\left(\lambda_{t}\right)$. The coefficient of interest is $\beta$ and its interpretation is as follows: $\beta>0$ means there is an attraction between natives and immigrants, while $\beta<0$ suggests a native outflow in response to the inflow of immigrants. Sá (2014) further points out that OLS estimation of Eq. 6 will likely lead to an upward bias in the estimate of $\beta$, since unobserved factors that attract immigrants into municipality could also attract natives. Therefore, I estimate (6) using the same shift-share instrument as before (with minor adjustments). ${ }^{22}$ Equation 6 is estimated using both municipality-level and subregional-level data, where 67 subregions approximate local labor markets. Results (OLS and IV) are presented in Table 7. Neither of the four coefficients is statistically significant, suggesting that immigration did not induce native mobility.

Another way to confirm that native sorting does not bias the main IV estimate is to re-estimate (1) using larger geographical units (subregions and regions). Mainland Finland consists of 18 administrative regions. The required underlying assumption states that if natives are mobile, they will sort within regions but not across regions (due to family ties and other costs of moving). Estimation results are shown in Table 19. All three estimates are negative and statistically significant at $1 \%$. The regional-level coefficient is smaller in magnitude than its municipalitylevel counterpart, but the coefficients are not statistically different from one another. The subregional-level coefficient, if anything, is larger in magnitude than the municipality-level estimate. These findings mitigate the concern that native sorting and spillover effects confound my analysis.

\footnotetext{
${ }^{21}$ Among others Borjas (2006), Card (2001, 2009), and Cortes (2008).

${ }^{22}$ The instrument distributes national net flows of immigrants by continent between $t-1$ and $t$, based on the 2003 distributions. The predicted net flow of immigrants in $i$ between $t-1$ and $t$ is then standardized by population in $t-1$.
} 
Table 7 Direct test of native mobility

\begin{tabular}{lllll}
\hline & $\begin{array}{l}\text { OLS } \\
\text { Net native flow } \\
\text { (municipality) }\end{array}$ & $\begin{array}{l}\text { IV } \\
\text { Net native flow } \\
\text { (municipality) }\end{array}$ & $\begin{array}{l}\text { OLS } \\
\text { Net native flow } \\
\text { (subregion) }\end{array}$ & $\begin{array}{l}\text { IV } \\
\text { (subregion) }\end{array}$ \\
\hline $\begin{array}{l}\text { Net immigrant flow } \\
\text { (municipality) }\end{array}$ & 0.118 & 0.709 & & \\
$\begin{array}{l}\text { Net immigrant flow } \\
\text { (subregion) }\end{array}$ & $(0.155)$ & $(1.104)$ & & -1.894 \\
$\begin{array}{l}\text { Observations } \\
\text { Mean of dep. variable }\end{array}$ & $-0.47 \%$ & $-0.47 \%$ & $-0.45 \%$ & $-0.45 \%$ \\
$\begin{array}{l}\text { Kleibergen-Paap rk Wald F-stat. } \\
\text { Anderson-Rubin chi-sq. test } p \text { val. }\end{array}$ & - & & 0.102 & 14.91 \\
\hline
\end{tabular}

Net native flow, annual net flow of Finnish citizens (\% of population at $t-1)$. Net immigrant flow, annual net flow of foreign citizens ( $\%$ of population at $t-1$ ). Standard errors in parentheses, clustered at respective levels (municipality, subregion). First two columns control for municipality fixed effects and election year fixed effects, while the last two columns control for subregion fixed effects and election year fixed effects. Data comes from Statistics Finland's StatFin database. *** Significant at the $0.1 \%$ level. ** Significant at the $1 \%$ level. * Significant at the $5 \%$ level. $\dagger$ Significant at the $10 \%$ level

\subsection{Immigration and voting for other parties}

An important aspect of any election study is understanding which parties benefit from one party's loss of votes. In the context of my analysis, this means finding out which parties gained the votes Finns Party lost to immigration. Thus, I re-estimate (1) using vote share of every main party as the dependent variable (see Section 3.2 for further description of these parties). ${ }^{23}$ Table 8 presents the results. As expected, the two parties that gained votes were the pro-immigration Green League and Swedish People's Party. Their positive coefficients indeed add up to the size of the Finns Party's negative coefficient. Moreover, the relative gains of these two parties were large, especially for the Swedish People's Party (57\% with respect to the sample mean).

\section{Discussion of potential mechanisms}

\subsection{Immigration, voter turnout, and protest vote}

In order to shed some light on the potential mechanisms through which immigration reduces Finns Party's support, I first consider the impact of immigration on voter turnout (share of eligible voters who cast a ballot in an election) and protest vote (fraction of total ballots that are invalid). As Table 9 shows, foreign municipal inmigration increased voter turnout although the effect is small (3\%). Protest vote was

\footnotetext{
${ }^{23}$ Left Alliance is not considered as it did not participate in all elections during the study period.
} 
Table 8 Immigration and election outcomes (all main parties)

\begin{tabular}{llllllll}
\hline & $(\mathrm{IV})$ & $(\mathrm{IV})$ & $(\mathrm{IV})$ & $(\mathrm{IV})$ & $(\mathrm{IV})$ & $(\mathrm{IV})$ & $(\mathrm{IV})$ \\
& Finns Party & Vihr & SFP/RKP & Kok & Kesk & SDP & KD \\
\hline Share of foreign citizens & $-3.351^{* * *}$ & $1.159 * * *$ & $2.303^{*}$ & $-0.900 \dagger$ & 0.645 & -1.013 & -0.317 \\
$(\%$ of population in 2003) & $(0.936)$ & $(0.295)$ & $(1.130)$ & $(0.527)$ & $(0.475)$ & $(0.833)$ & $(0.251)$ \\
Observations & 2,079 & 2,079 & 2,079 & 2,079 & 2,079 & 2,079 & 2,079 \\
Mean of dep. variable & $12 \%$ & $5 \%$ & $4.07 \%$ & $17.4 \%$ & $33.4 \%$ & $17.5 \%$ & $3.95 \%$ \\
Std. dev. of dep. variable & $7.56 \%$ & $4.36 \%$ & $13.6 \%$ & $10 \%$ & $16.8 \%$ & $12.6 \%$ & $3.38 \%$ \\
Kleibergen-Paap rk Wald F-stat. & 22.77 & 22.77 & 22.77 & 22.77 & 22.77 & 22.77 & 22.77 \\
\hline
\end{tabular}

Finns Party, Finns Party's share of valid votes; Vihr, Green League's share of valid votes; SFP/RKP, Swedish People's Party's share of valid votes; Kok, National Coalition Party's share of valid votes; Kesk, Centre Party's share of valid votes; SDP, Social Democratic Party's share of valid votes; KD, Christian Democrats' share of valid votes. Standard errors in parentheses, clustered at municipality level. All regressions control for municipality fixed effects, election year fixed effects, region-by-election year fixed effects, and the following municipality-specific time-varying controls (in lagged form): $\log$ of population, population density, share of females, share of tertiary educated, share of aged $65+$, ratio of skilled to unskilled labor, total crime rate, unemployment rate, median household income. Data comes from Statistics Finland's StatFin database. *** Significant at the $0.1 \%$ level. ** Significant at the $1 \%$ level. * Significant at the $5 \%$ level. $\uparrow$ Significant at the $10 \%$ level.

not affected. This suggests immigration induced natives' participation in the election process, potentially activating anti-far-right voters who would otherwise not vote. It is also worth noting that the OLS counterparts to all coefficients in both Tables 8 and 9 are attenuated towards zero (see Tables 20 and 21 for comparison), further suggesting the presence of measurement error in the share of foreign citizens.

Table 9 Immigration and voter turnout, protest vote

\begin{tabular}{lll}
\hline & $($ IV) & (IV) \\
& Voter turnout & Protest vote \\
\hline Share of foreign citizens & $1.711^{* * *}$ & 0.021 \\
$(\%$ of population in 2003) & $(0.530)$ & $(0.025)$ \\
Observations & 2,079 & 2,079 \\
Mean of dep. variable & $59.7 \%$ & $0.51 \%$ \\
Std. dev. of dep. variable & $15.4 \%$ & $0.24 \%$ \\
Kleibergen-Paap rk Wald F-stat. & 22.77 & 22.77 \\
\hline
\end{tabular}

Voter turnout, share of eligible voters who cast ballot in election. Protest vote, share of invalid ballots. Standard errors in parentheses, clustered at municipality level. Both regressions control for municipality fixed effects, election year fixed effects, region-by-election year fixed effects, and the following municipalityspecific time-varying controls (in lagged form): log of population, population density, share of females, share of tertiary educated, share of aged $65+$, ratio of skilled to unskilled labor, total crime rate, unemployment rate, median household income. Data comes from Statistics Finland's StatFin database. *** Significant at the $0.1 \%$ level. ** Significant at the $1 \%$ level. * Significant at the $5 \%$ level. $\dagger$ Significant at the $10 \%$ level. 


\subsection{Heterogeneity analysis and intergroup contact theory}

Next, I test for the heterogeneity in the effect with respect to various initial conditions. In particular, first, the sample is split based on the median values of the following initial conditions: population, population density, immigrant share, Finns Party's vote share, share of tertiary educated, skill ratio, median household income, and unemployment rate. ${ }^{24}$ Then, separately for each initial condition, the share of foreign citizens is interacted with the above-median/below-median dummies. All regressions are estimated using the same IV as before. Results are reported in Table 10. The strong negative effect is present across municipalities regardless of their initial population size, density, level of education, skill ratio, median income, and unemployment rate. The coefficient is remarkably stable across different specifications both in terms of its magnitude and statistical significance. However, columns (3) and (4) do show some heterogeneity in the effect, since in both cases, the hypothesis that the two coefficients are equal can be rejected. Column (4) suggests that municipalities with higher pre-existing support for the far-right experienced a smaller reduction in antiimmigrant voting than the municipalities where Finns Party was less popular to begin with. However, the effect of immigration on high-nationalist municipalities is still negative and sizable, suggesting that the inflow of immigrants even into the far-right "strongholds" can ameliorate natives' attitudes towards foreigners.

The most interesting result of Table 10 is presented in column (3). The negative effect of immigration on the Finns Party's vote share is found only in municipalities with high pre-existing immigrant share. In other words, places where natives are already living side-by-side with immigrants are the ones that experience a reduction in anti-immigrant voting as a result of further immigrant inflow. This suggests that previous exposure to immigrants matters, providing some evidence in support of Allport (1954)'s intergroup contact theory. The importance of sustained contact between natives and immigrants is further strengthened by the results from an additional heteronegeity analysis, in which I split the sample by the 25th and 75th percentiles (Table 22). The negative effect is only present in the municipalities in the top quartile of the initial immigrant share (Table 22, col. 3). Interestingly, Table 22 also reveals that the effect is stronger in most rural places compared to the most urban communities (col. 2). However, given the weak first stage, this result has to be treated with caution.

\subsection{Welfare-state channel}

Last but not least, the welfare-state channel is yet another potential mechanism that could explain my main finding. There are two possible policy scenarios through which immigration affects the welfare system of the host country. On the one hand, migration can lead to changes in tax rates while per capita benefits are kept constant (tax adjustment model). On the other hand, tax rates might remain unchanged

\footnotetext{
${ }^{24}$ All (except Finns Party's vote share) are measured at the beginning of 2004. Finns Party's vote share is taken from the 2003 parliamentary election since the 2004 European election took place after the EU enlargement.
} 


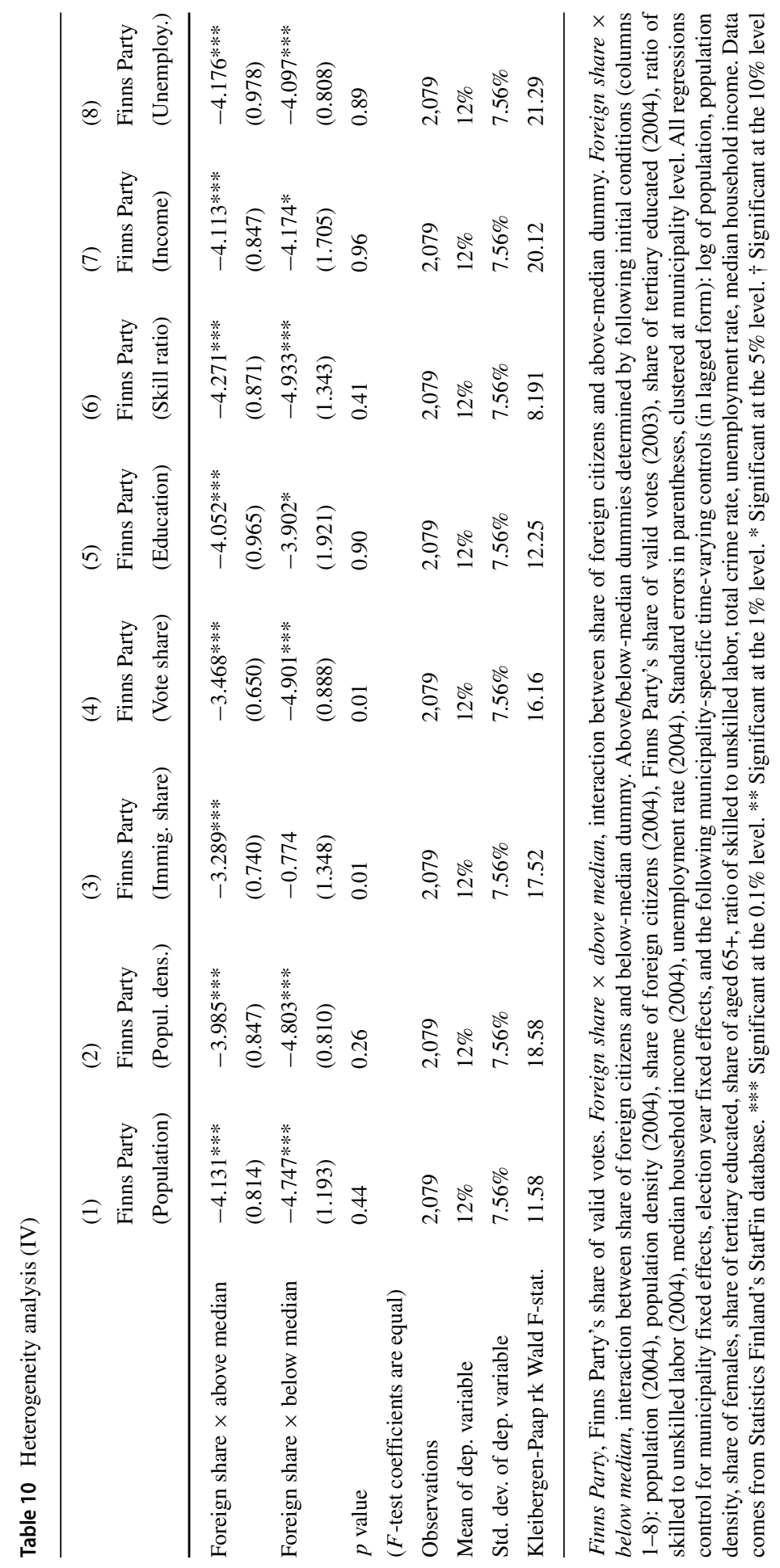


Table 11 Immigration and municipality tax revenue and spending (2006-2010)

\begin{tabular}{|c|c|c|c|c|c|c|}
\hline & $\begin{array}{l}\text { (IV) } \\
\text { Total } \\
\text { tax } \\
\text { revenue }\end{array}$ & $\begin{array}{l}\text { (IV) } \\
\text { Income } \\
\text { tax } \\
\text { revenue }\end{array}$ & $\begin{array}{l}\text { (IV) } \\
\text { Property } \\
\text { tax } \\
\text { revenue }\end{array}$ & $\begin{array}{l}\text { (IV) } \\
\text { Corporate } \\
\text { tax } \\
\text { revenue }\end{array}$ & $\begin{array}{l}\text { (IV) } \\
\text { Social and } \\
\text { health care } \\
\text { spending }\end{array}$ & $\begin{array}{l}\text { (IV) } \\
\text { Edu. and } \\
\text { cultural } \\
\text { spending }\end{array}$ \\
\hline $\begin{array}{l}\text { Share of foreign citizens } \\
\text { (\% of population in 2003) }\end{array}$ & $\begin{array}{l}39.08 \\
(43.74)\end{array}$ & $\begin{array}{l}56.04 \dagger \\
(33.74)\end{array}$ & $\begin{array}{l}-2.43 \\
(13.20)\end{array}$ & $\begin{array}{l}-13.91 \\
(20.06)\end{array}$ & $\begin{array}{l}-11.70 \\
(142.7)\end{array}$ & $\begin{array}{l}-45.78 \\
(43.42)\end{array}$ \\
\hline Observations & 1,485 & 1,485 & 1,485 & 1,485 & 1,485 & 1,485 \\
\hline Mean of dep. variable & $2,697.7$ & $2,323.9$ & 163.4 & 210.4 & $3,235.5$ & $1,268.5$ \\
\hline Std. dev. of dep. variable & 527.4 & 467.5 & 123.9 & 134.4 & 711.6 & 260.2 \\
\hline Kleibergen-Paap rk Wald F-stat. & 21.81 & 21.81 & 21.81 & 21.81 & 21.81 & 21.81 \\
\hline
\end{tabular}

Total tax revenue, total municipality tax revenue (EUR per capita); Income tax revenue, municipality personal income tax revenue (EUR per capita); Property tax revenue, municipality property tax revenue (EUR per capita); Corporate tax revenue, municipality corporate income tax revenue (EUR per capita); Social and health care spending, municipality spending on social and health care services (EUR per capita); Edu. and cultural spending, municipality spending on education and cultural activities (EUR per capita). Standard errors in parentheses, clustered at municipality level. All regressions control for municipality fixed effects, election year fixed effects, region-by-election year fixed effects, and the following municipalityspecific time-varying controls (in lagged form): $\log$ of population, population density, share of females, share of tertiary educated, share of aged $65+$, ratio of skilled to unskilled labor, unemployment rate, median household income. Data comes from Statistics Finland's database titled Economic data reported by municipalities and joint municipal boards. *** Significant at the $0.1 \%$ level. ** Significant at the $1 \%$ level. * Significant at the $5 \%$ level. $\dagger$ Significant at the $10 \%$ level

while per capita benefits adjust (benefit adjustment model). Under both scenarios, if immigrants are, on average, net contributors to the system (i.e., their tax contributions exceed the amount of social assistance they receive), both high-skilled and low-skilled natives will likely benefit from the presence of foreign workers due to a positive welfare spillover (Facchini and Mayda 2009, 2012). Therefore, an influx of such immigrants can ameliorate natives' attitudes towards them, and thus make natives less supportive of the anti-immigrant Finns Party.

In the absence of any individual-level data on immigrant tax contributions and social assistance program take-up, I turn to municipality-level data instead. Using data from 2006-2010 (including non-election years), I consider the effect of immigration on municipal tax revenue and spending. ${ }^{25}$ The analysis uses the same IV as the main estimation. I find a small positive effect of municipal in-migration of foreign citizens on per capita personal income tax revenue (2.5\%), although the coefficient is statistically significant only at $10 \%$ (Table 11 , column 2 ). On the other hand, there is clearly no effect of immigration on per capita property tax revenue or corporate tax revenue (Table 11, cols. 3 and 4).

The provision of social welfare in Finland is delegated to individual municipalities (source: Ministry of Social Affairs and Health, 2006). As Hytti and Paananen (2003)

\footnotetext{
${ }^{25}$ Data comes from Statistics Finland's database titled "Economic data reported by municipalities and joint municipal boards." Only limited data is available after 2010.
} 
explain, immigrants with a resident permit valid for at least a year have the same rights to social security (i.e., unemployment benefits, family benefits linked to childbirth and child-rearing, and income support) as the native population. As Table 11, column (5) suggests, immigration had virtually no effect on municipal per capita spending on social and health care services. In addition, there was no effect of immigration on per capita spending on education and cultural activities. These findings suggest that an inflow of foreigners into a municipality did not overburden the provision of social welfare and other public services. Together with the positive effect on municipal income tax revenue, this suggests that welfare-state channel appears to be a plausible mechanism explaining the main finding.

\section{Conclusion}

This paper uses a novel panel dataset to study the effect of immigration on voting for the far-right Finns Party in Finland. Using an instrumental variable approach based on previous settlement patterns of immigrants, I show that municipal in-migration of foreign citizens has a statistically significant and sizable negative effect on Finns Party's electoral support in national elections. In particular, a 1 percentage point increase in the share of foreign citizens in a municipality decreases Finns Party's vote share by 3.5 percentage points ( $28 \%$ of the mean). This result-albeit consistent in magnitude with the negative estimates in Steinmayr (2018) and Dustmann et al. (2019)—runs contrary to most findings in the previous literature. Placebo tests using pre-period data suggest that the negative effect is not driven by persistent trends at the municipality level. The votes Finns Party loses due to immigration are captured by the two pro-immigration parties- the Green League and the Swedish People's Party.

To explore the potential mechanisms driving my main finding, I first show that immigration increases local voter turnout, potentially activating a larger portion of the pro-immigration base in the municipality. In addition, heterogeneity analysis reveals that the negative effect of immigration on far-right popularity is present only in the communities with large initial immigrant share. This provides some evidence in support of Allport (1954)'s intergroup contact theory, which emphasizes the importance of sustained contact between natives and immigrants in ameliorating the local anti-immigrant sentiments. Finally, I provide some evidence consistent with the welfare-state channel as a potential mechanism. In particular, I find that foreign inmigration increases per capita municipal income tax revenue, while the per capita spending on social services, health care, and education remain unaffected.

Given the serious nature of the threat far-right parties pose to the European integration process, Europe's security (with the ongoing threat from the Russian Federation), and potentially even the future of liberal democracy itself, the role of far-right parties in Western societies remains one of the most important topics of the public debate in Europe today. This paper contributes to the debate by presenting a unique case study showing that under some conditions, local immigrant inflow can actually reduce far-right popularity. To better understand the complexity of the relationship between immigration and far-right voting, future research needs to carefully 
address the interplay between the effects of micro-level and macro-level exposure to immigrants on far-right votes across the continent.

Acknowledgment I would like to thank the Editor-in-Chief Klaus F. Zimmermann, the Managing Editor Madeline Zavodny, and the three anonymous referees of this journal. I feel that the paper has substantially improved thanks to their insightful comments and suggestions. I am also thankful to Osea Giuntella, Werner Troesken, Daniel Berkowitz, Isabel Ruiz, Gianmarco Daniele, and Paolo Pinotti for their helpful comments and suggestions. Last but not least, I am grateful to seminar attendants at Bocconi University, University of Pittsburgh, the Second Workshop on Immigration, Health, and Well-Being (University of Oxford, 2017), and the Czech Economic Society \& Slovak Economic Association Meeting (Czech Rep., 2019). Any conclusions are my own.

Data availability Data is available from author's personal website.

Code availability Stata 15 code is available from author's personal website.

\section{Compliance with ethical standards}

Conflict of interests The author declares that he has no conflict of interest.

Open Access This article is licensed under a Creative Commons Attribution 4.0 International License, which permits use, sharing, adaptation, distribution and reproduction in any medium or format, as long as you give appropriate credit to the original author(s) and the source, provide a link to the Creative Commons licence, and indicate if changes were made. The images or other third party material in this article are included in the article's Creative Commons licence, unless indicated otherwise in a credit line to the material. If material is not included in the article's Creative Commons licence and your intended use is not permitted by statutory regulation or exceeds the permitted use, you will need to obtain permission directly from the copyright holder. To view a copy of this licence, visit http://creativecommons.org/ licenses/by/4.0/.

\section{Appendix A. Description of municipality-specific time-varying controls}

- Log of total population - to capture demographic dynamics (Barone et al. 2016).

- Population density (inhabitants per $\mathrm{km}^{2}$; proxy for urbanization) - far-right parties tend to gather larger support among people from rural municipalities.

- Share of women in the adult population - women tend to be less supportive of the Finns Party (Niemi 2012).

- Share of old people in the adult population (65 and above) - far-right parties generally score high points among old people (appeal to tradition, conservatism, etc.).

- Total crime rate (crimes per 100,000 inhabitants) - far-right parties often campaign on issues related to law and order. Higher crime rate might therefore lead to higher Finns Party's popularity.

- Unemployment rate - poor economic performance of a municipality reflected in high unemployment rate is expected to be a strong predictor of far-right support.

- Share of population (25-64) with tertiary education - people with university education are less likely to accept nationalist-populist agenda, and therefore are less likely to vote for the far-right parties. 
- Skill ratio (skilled/unskilled workers) - proxied by the number of people (aged 20 or above) with education levels 2 and 3 divided by the number of people with education level 1 (Mayda 2006). Level 1 corresponds to ISCED ${ }^{26}$ categories 0 , 1, 2 (i.e., basic education), level 2 to ISCED categories 3, 4 (i.e., completed upper secondary education), and level 3 to ISCED categories 5-8 (i.e., tertiary education). Literature suggests that low-skilled workers are more likely to vote for far-right parties than high-skilled ones.

- Median disposable income of household unit per consumption unit (in EUR) controls for differences in standards of living across municipalities. Municipalities with higher income level should be less prone to vote for the Finns Party. There are two drawbacks with this variable: first, it is not adjusted for the variation in price levels across municipalities. Second, according to Statistics Finland, due to revisions in income concepts, 1995-2009 and 2010-2014 data are not fully comparable. Nevertheless, since municipality-level GDP data is not available, median disposable income together with the unemployment rate are the best economic measures on the municipality level that I have available.

\section{B Robustness checks and further results}

Table 12 Main IV - first stage estimates

\begin{tabular}{llll}
\hline & $(1)$ & $(2)$ & $(3)$ \\
& $\begin{array}{l}\text { Share of foreign } \\
\text { citizens }\end{array}$ & $\begin{array}{l}\text { Share of foreign } \\
\text { citizens }\end{array}$ & $\begin{array}{l}\text { Share of foreign } \\
\text { citizens }\end{array}$ \\
\hline Predicted share of foreign citizens & $0.943^{* * *}$ & $0.653^{* * *}$ & $0.555^{* * *}$ \\
(\% of population in 2003) & $(0.120)$ & $(0.111)$ & $(0.116)$ \\
Municipality/election year FE & Yes & Yes & Yes \\
Time-varying controls (lag) & & Yes & Yes \\
Region FE $\times$ election year FE & & & Yes \\
Observations & 2,079 & 2,079 & 2,079 \\
Mean of dep. variable & $1.46 \%$ & $1.46 \%$ & $1.46 \%$ \\
Kleibergen-Paap rk Wald F-stat. & 62.32 & 34.53 & 22.77 \\
Stock-Yogo weak ID test (10\% max. IV size c.v.) & 16.38 & 16.38 & 16.38
\end{tabular}

Share of foreign citizens, share of foreign citizens (\% of population in 2003). Standard errors in parentheses, clustered at municipality level. Time-varying controls: log of population, population density, share of females, share of tertiary educated, share of aged 65+, ratio of skilled to unskilled labor, total crime rate, unemployment rate, median household income. Data comes from Statistics Finland's StatFin database. $* * *$ Significant at the $0.1 \%$ level. ** Significant at the $1 \%$ level. * Significant at the $5 \%$ level. $\dagger$ Significant at the $10 \%$ level

\footnotetext{
${ }^{26}$ UNESCO's International Standard Classification of Education.
} 
Table 13 Main IV estimates with varying covariates

\begin{tabular}{lllllll}
\hline & (IV) & (IV) & (IV) & (IV) & (IV) & (IV) \\
& Finns & Finns & Finns & Finns & Finns & Finns \\
& Party & Party & Party & Party & Party & Party \\
\hline Share of foreign citizens & $-1.464 * * *-1.547 * * *-2.357 * * *-4.031 * * *-4.103 * * *-3.351^{* * *}$ & \\
(\% of population in 2003) & $(0.373)$ & $(0.388)$ & $(0.512)$ & $(0.817)$ & $(0.809)$ & $(0.936)$ \\
Municipality/election year FE & Yes & Yes & Yes & Yes & Yes & Yes \\
Population density (1-year lag) & & Yes & Yes & Yes & Yes & Yes \\
Female share (1-year lag) & & Yes & Yes & Yes & Yes & Yes \\
Share aged 65+ (1-year lag) & & Yes & Yes & Yes & Yes & Yes \\
Share tertiary educated (1-year lag) & & & Yes & Yes & Yes & Yes \\
Log of population (1-year lag) & & & Yes & Yes & Yes & Yes \\
Skill ratio (1-year lag) & & & & Yes & Yes & Yes \\
Total crime rate (1-year lag) & & & & Yes & Yes & Yes \\
Unemployment rate (1-year lag) & & & & & Yes & Yes \\
Median household income (1-year lag) & & & & & Yes & Yes \\
Region FE x election year FE & & & & & & Yes \\
Observations & 2,079 & 2,079 & 2,079 & 2,079 & 2,079 & 2,079 \\
Mean of dep. variable & $12 \%$ & $12 \%$ & $12 \%$ & $12 \%$ & $12 \%$ & $12 \%$ \\
Std. dev. of dep. variable & $7.56 \%$ & $7.56 \%$ & $7.56 \%$ & $7.56 \%$ & $7.56 \%$ & $7.56 \%$ \\
Kleibergen-Paap rk Wald F-stat. & 62.32 & 74.98 & 52.93 & 34.64 & 34.53 & 22.77 \\
\hline
\end{tabular}

Finns Party, Finns Party's share of valid votes. Population density, \# of inhabitants per kn² ${ }^{2}$ Female share, $\%$ of women in the adult population; Share aged $65+, \%$ of people aged $65+$ in the adult population; Share tertiary educated, \% of population ages 25-64 with tertiary education; Log of population, $\log$ of total population; Skill ratio, ratio of skilled to unskilled workers (among those aged 20+); Total crime rate, \# of crimes per 100,000 inhabitants; Unemployment rate, \# of unemployed (as \% of labor force); Median household income, median household disposable income per consumption unit (in EUR). Standard errors in parentheses, clustered at municipality level. Data comes from Statistics Finland's StatFin database. *** Significant at the $0.1 \%$ level. ** Significant at the $1 \%$ level. * Significant at the 5\% level. $\uparrow$ Significant at the $10 \%$ level 
Table 14 IV results using 1991 as base year (second stage)

\begin{tabular}{llll}
\hline & $(1)$ & $(2)$ & $(3)$ \\
& Finns Party & Finns Party & Finns Party \\
\hline $\begin{array}{l}\text { Share of foreign citizens } \\
\text { (\% of population in 1991) }\end{array}$ & $-2.379^{* * *}$ & $-5.707^{* * *}$ & $-5.026^{*}$ \\
Municipality/election year FE & $(0.544)$ & $(1.445)$ & $(2.093)$ \\
Time-varying controls (lag) & Yes & Yes & Yes \\
Region FE $\times$ election year FE & & Yes & Yes \\
Observations & 2,079 & & Yes \\
Mean of dep. variable & $12 \%$ & 2,079 & 2,079 \\
Std. dev. of dep. variable & $7.56 \%$ & $12 \%$ & $12 \%$ \\
Kleibergen-Paap rk Wald F-stat. & 32.65 & $7.56 \%$ & $7.56 \%$ \\
Anderson-Rubin chi-sq. test $p$ val. & & 14.81 & 6.51 \\
\hline
\end{tabular}

Finns Party, Finns Party's share of valid votes. Standard errors in parentheses, clustered at municipality level. Time-varying controls: log of population, population density, share of females, share of tertiary educated, share of aged $65+$, ratio of skilled to unskilled labor, total crime rate, unemployment rate, median household income. Data comes from Statistics Finland's StatFin database. *** Significant at the $0.1 \%$ level. ** Significant at the $1 \%$ level. * Significant at the $5 \%$ level. $\dagger$ Significant at the $10 \%$ level

Table 15 Exclusion of 2009 and 2014 European elections (IV results)

\begin{tabular}{llll}
\hline & $(1)$ & $(2)$ & $(3)$ \\
& Finns Party & Finns Party & Finns Party \\
\hline Share of foreign citizens & $-1.802^{* * *}$ & $-4.365^{* * *}$ & $-3.954^{* * * *}$ \\
$(\%$ of population in 2003) & $(0.424)$ & $(0.879)$ & $(1.126)$ \\
Municipality/election year FE & Yes & Yes & Yes \\
Time-varying controls (lag) & & Yes & Yes \\
Region FE $\times$ election year FE & & & Yes \\
Observations & 1,485 & 1,485 & 1,485 \\
Mean of dep. variable & $11.9 \%$ & $11.9 \%$ & $11.9 \%$ \\
Std. dev. of dep. variable & $8.53 \%$ & $8.53 \%$ & $8.53 \%$ \\
Kleibergen-Paap rk Wald F-stat. & 62.50 & 33.60 & 22.06 \\
\hline
\end{tabular}

Finns Party, Finns Party's share of valid votes. Standard errors in parentheses, clustered at municipality level. Time-varying controls: log of population, population density, share of females, share of tertiary educated, share of aged $65+$, ratio of skilled to unskilled labor, total crime rate, unemployment rate, median household income. Data comes from Statistics Finland's StatFin database. *** Significant at the $0.1 \%$ level. ** Significant at the $1 \%$ level. * Significant at the $5 \%$ level. $†$ Significant at the $10 \%$ level

\section{Checking for outliers: exclusion of 9 largest Finnish municipalities}

To check if outliers are not driving the main results, I exclude 9 largest municipalities from the analysis. These municipalities are the only ones with population of 100,000 or more during the 2006-2015 period. The following municipalities are omitted: Helsinki, Espoo, Tampere, Vantaa, Turku, Oulu, Jyväskylä, Lahti, and Kuopio. With 
Table 169 largest municipalities omitted (IV results)

\begin{tabular}{|c|c|c|c|}
\hline & $\begin{array}{l}\text { (1) } \\
\text { Finns Party }\end{array}$ & $\begin{array}{l}(2) \\
\text { Finns Party }\end{array}$ & $\begin{array}{l}(3) \\
\text { Finns Party }\end{array}$ \\
\hline $\begin{array}{l}\text { Share of foreign citizens } \\
\text { (\% of population in 2003) }\end{array}$ & $\begin{array}{l}-1.889^{* * *} \\
(0.564)\end{array}$ & $\begin{array}{l}-5.001 * * * \\
(1.136)\end{array}$ & $\begin{array}{l}-4.975^{*} \\
(2.180)\end{array}$ \\
\hline Municipality/election year FE & Yes & Yes & Yes \\
\hline Time-varying controls (lag) & & Yes & Yes \\
\hline Region FE $\times$ election year FE & & & Yes \\
\hline Observations & 2,016 & 2,016 & 2,016 \\
\hline Mean of dep. variable & $12.1 \%$ & $12.1 \%$ & $12.1 \%$ \\
\hline Std. dev. of dep. variable & $7.6 \%$ & $7.6 \%$ & $7.6 \%$ \\
\hline Kleibergen-Paap rk Wald F-stat. & 46.34 & 23.78 & 10.74 \\
\hline Anderson-Rubin chi-sq. test $p$ val. & & & 0.003 \\
\hline
\end{tabular}

Finns Party, Finns Party's share of valid votes. Standard errors in parentheses, clustered at municipality level. Time-varying controls: log of population, population density, share of females, share of tertiary educated, share of aged $65+$, ratio of skilled to unskilled labor, total crime rate, unemployment rate, median household income. Data comes from Statistics Finland's StatFin database. *** Significant at the 0.1\% level. ** Significant at the $1 \%$ level. * Significant at the 5\% level. $†$ Significant at the $10 \%$ level

the exception of Oulu (which is in central Finland), all of them are located in the southern part of the country. Results are presented in Table 16. Overall, the analysis suggests that outliers do not drive the main IV estimates.

Table 17 Separate IV analysis by election type

\begin{tabular}{llll}
\hline & $\begin{array}{l}\text { (IV) } \\
\text { Finns Party } \\
\text { (parliamentary) }\end{array}$ & $\begin{array}{l}\text { (IV) } \\
\text { Finns Party } \\
\text { (presidential) }\end{array}$ & $\begin{array}{l}\text { Finns Party } \\
\text { (European) }\end{array}$ \\
\hline Share of foreign citizens & $-3.941^{* *}$ & $-2.963^{* *}$ & $-2.236^{* *}$ \\
$(\%$ of population in 2003) & $(1.204)$ & $(0.740)$ & $(0.845)$ \\
Observations & 891 & 594 & 594 \\
Mean of dep. variable & $14.9 \%$ & $7.33 \%$ & $12.3 \%$ \\
Std. dev. of dep. variable & $9.31 \%$ & $4.21 \%$ & $4.23 \%$ \\
Kleibergen-Paap rk Wald F-stat. & 20.40 & 21.70 & 18.92 \\
\hline
\end{tabular}

Finns Party, Finns Party's share of valid votes. First column uses data from parliamentary elections in 2007, 2011, 2015; second column uses data from presidential elections in 2006, 2012; third column uses data from European parliamentary elections in 2009 and 2014. Standard errors in parentheses, clustered at municipality level. All regressions control for municipality fixed effects, election year fixed effects, region-by-election year fixed effects, and the following municipality-specific time-varying controls (in lagged form): $\log$ of population, population density, share of females, share of tertiary educated, share of aged $65+$, ratio of skilled to unskilled labor, total crime rate, unemployment rate, median household income. Data comes from Statistics Finland's StatFin database. *** Significant at the $0.1 \%$ level. ** Significant at the $1 \%$ level. * Significant at the $5 \%$ level. $\dagger$ Significant at the $10 \%$ level 
Table 18 Controlling for lagged share of foreign citizens

\begin{tabular}{llll}
\hline & $(\mathrm{IV})$ & $(\mathrm{IV})$ & (IV) \\
& Finns Party & Finns Party & Finns Party \\
\hline Share of foreign citizens & $-8.893^{* * *}$ & $-9.296^{* * * *}$ & $-7.131^{* * *}$ \\
$(\%$ of population in 2003) & $(1.883)$ & $(2.169)$ & $(2.061)$ \\
Share of foreign citizens (2-year lag) & Yes & Yes & Yes \\
(\% of population in 2003) & & & Yes \\
Municipality/election year FE & Yes & Yes & Yes \\
Time-varying controls (lag) & & Yes & Yes \\
Region FE $\times$ election year FE & & & 2,079 \\
Observations & 2,079 & 2,079 & $12 \%$ \\
Mean of dep. variable & $12 \%$ & $12 \%$ & $7.56 \%$ \\
Std. dev. of dep. variable & $7.56 \%$ & $7.56 \%$ & 10.62 \\
Kleibergen-Paap rk Wald F-stat. & 12.01 & 12.19 & 0.000 \\
Anderson-Rubin chi-sq. test $p$ val. & 0.000 & 0.000 & \\
\hline
\end{tabular}

Finns Party, Finns Party's share of valid votes. Standard errors in parentheses, clustered at municipality level. Time-varying controls: log of population, population density, share of females, share of tertiary educated, share of aged $65+$, ratio of skilled to unskilled labor, total crime rate, unemployment rate, median household income. Data comes from Statistics Finland's StatFin database. *** Significant at the $0.1 \%$ level. ** Significant at the $1 \%$ level. * Significant at the $5 \%$ level. $\dagger$ Significant at the $10 \%$ level

Table 19 IV sensitivity to native sorting

\begin{tabular}{llll}
\hline & (IV) & (IV) & (IV) \\
& $\begin{array}{l}\text { Finns Party } \\
\text { (municipality) }\end{array}$ & $\begin{array}{l}\text { Finns Party } \\
\text { (subregion) }\end{array}$ & $\begin{array}{l}\text { Finns Party } \\
\text { (region) }\end{array}$ \\
\hline Share of foreign citizens (\% of population in 2003) & $-1.820 * * *$ & & $-2.619 * * *$ \\
Share of foreign citizens (\% of population in 2003) & $(0.285)$ & $(0.542)$ & $-1.428 * *$ \\
& & & $(0.351)$ \\
Share of foreign citizens (\% of population in 2003) & & 469 & 126 \\
Observations & & $11.7 \%$ & $11.7 \%$ \\
Mean of dep. variable & 2,079 & $6.95 \%$ & $6.49 \%$ \\
Standard deviation of dep. variable & $12 \%$ & 40.08 & 60.61 \\
Kleibergen-Paap rk Wald F-stat. & $7.56 \%$. & 97.71 & \\
\hline
\end{tabular}

Finns Party, Finns Party's share of valid votes. Standard errors in parentheses, clustered at respective levels (municipality, subregion, region). All regressions control for election year fixed effects, and the following municipality/subregion/region-specific time-varying controls (in lagged form): log of population, population density, share of females, share of tertiary educated, share of aged $65+$, ratio of skilled to unskilled labor, total crime rate, unemployment rate, median household income. Data comes from Statistics Finland's StatFin database. *** Significant at the $0.1 \%$ level. ** Significant at the $1 \%$ level. * Significant at the $5 \%$ level. $\dagger$ Significant at the $10 \%$ level 
Table 20 Immigration and election outcomes (all main parties): OLS

\begin{tabular}{llllllll}
\hline & $(1)$ & $(2)$ & $(3)$ & $(4)$ & $(5)$ & $(6)$ & $(7)$ \\
& Finns Party & Vihr & SFP/RKP & Kok & Kesk & SDP & KD \\
\hline Share of foreign citizens & $-0.656^{*}$ & 0.147 & $0.746^{*}$ & -0.208 & 0.235 & -0.162 & -0.074 \\
$(\%$ of population in 2003) & $(0.303)$ & $(0.094)$ & $(0.333)$ & $(0.160)$ & $(0.224)$ & $(0.224)$ & $(0.110)$ \\
Observations & 2,079 & 2,079 & 2,079 & 2,079 & 2,079 & 2,079 & 2,079 \\
Adjusted R-squared & 0.880 & 0.881 & 0.637 & 0.881 & 0.598 & 0.939 & 0.513 \\
Mean of dep. variable & $12 \%$ & $5 \%$ & $4.07 \%$ & $17.4 \%$ & $33.4 \%$ & $17.5 \%$ & $3.95 \%$ \\
Std. dev. of dep. variable & $7.56 \%$ & $4.36 \%$ & $13.6 \%$ & $10 \%$ & $16.8 \%$ & $12.6 \%$ & $3.38 \%$ \\
\hline
\end{tabular}

Finns Party, Finns Party's share of valid votes; Vihr, Green League's share of valid votes; SFP/RKP, Swedish People's Party's share of valid votes; Kok, National Coalition Party's share of valid votes; Kesk, Centre Party's share of valid votes; SDP, Social Democratic Party's share of valid votes; KD, Christian Democrats' share of valid votes. Standard errors in parentheses, clustered at municipality level. All regressions control for municipality fixed effects, election year fixed effects, region-by-election year fixed effects, and the following municipality-specific time-varying controls (in lagged form): $\log$ of population, population density, share of females, share of tertiary educated, share of aged $65+$, ratio of skilled to unskilled labor, total crime rate, unemployment rate, median household income. Data comes from Statistics Finland's StatFin database. *** Significant at the $0.1 \%$ level. ** Significant at the $1 \%$ level. * Significant at the $5 \%$ level. $\dagger$ Significant at the $10 \%$ level

Table 21 Immigration and voter turnout, protest vote: OLS

(1)

(2)

Voter turnout

Protest vote

\begin{tabular}{lll}
\hline Share of foreign citizens & $0.369 *$ & 0.005 \\
(\% of population in 2003) & $(0.154)$ & $(0.012)$ \\
Observations & 2,079 & 2,079 \\
Adjusted R-squared & 0.985 & 0.453 \\
Mean of dep. variable & $59.7 \%$ & $0.51 \%$ \\
Std. dev. of dep. variable & $15.4 \%$ & $0.24 \%$
\end{tabular}

Voter turnout, share of eligible voters who cast ballot in election. Protest vote, share of invalid ballots. Standard errors in parentheses, clustered at municipality level. Both regressions control for municipality fixed effects, election year fixed effects, region-by-election year fixed effects, and the following municipalityspecific time-varying controls (in lagged form): log of population, population density, share of females, share of tertiary educated, share of aged $65+$, ratio of skilled to unskilled labor, total crime rate, unemployment rate, median household income. Data comes from Statistics Finland's StatFin database. *** Significant at the $0.1 \%$ level. ** Significant at the $1 \%$ level. * Significant at the $5 \%$ level. $\dagger$ Significant at the $10 \%$ level 


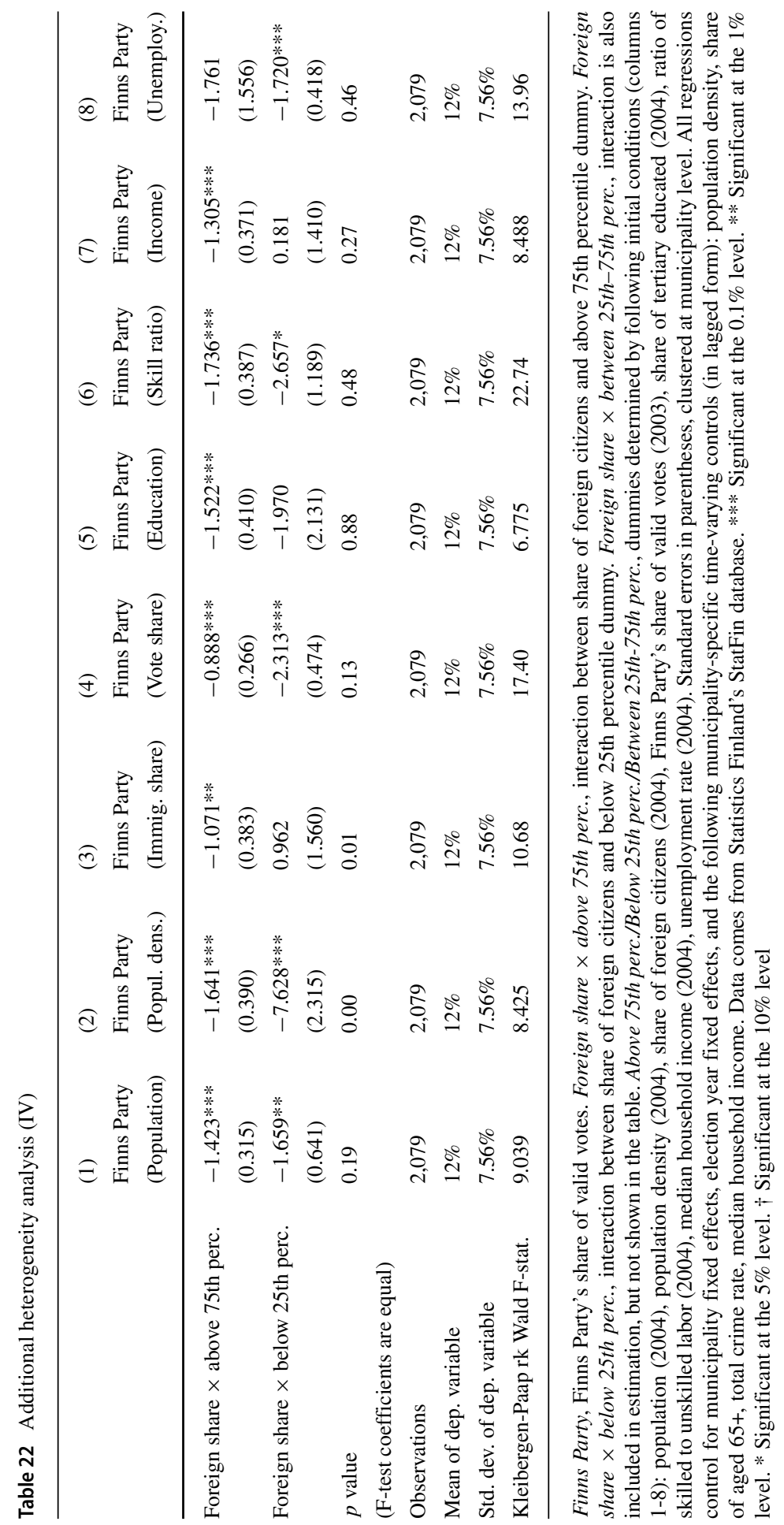




\section{References}

Akay A, Constant A, Giulietti C (2014) The impact of immigration on the well-being of natives. J Econ Behav Org 103:72-92

Akay A, Constant A, Giulietti C, Guzi M (2017) Ethnic diversity and well-being. J Popul Econ 30(1):265306

Allport G (1954) The nature of prejudice. Addison-Wesley, Reading, MA

Altonji JG, Card D (1991) The effects of immigration on the labor market outcomes of less-skilled natives. In: Abowd JM, Freeman RB (eds) Immigration, trade, and the labor market. University of Chicago Press

Anderson CJ (1996) Economics, politics, and foreigners: populist party support in Denmark and Norway. Elect Stud 15(4):497-511

Angrist JD, Pischke J-S (2008) Mostly harmless econometrics: an empiricist's companion. Princeton University Press, Princeton, New Jersey

Arter D (2008) From a contingent party system to party system convergence? Mapping party system change in postwar Finland. Scandinavian Polit Stud 32:221-239

Arter D (2010) The breakthrough of another West European populist radical right party? Govern Oppos 45(4):484-504

Aydemir A, Borjas GJ (2011) Attenuation bias in measuring the wage impact of immigration. J Labor Econ 29(1):69-112

Barone G, D'Ignazio A, de Blasio G, Naticchioni P (2016) Mr. Rossi, Mr. Hu and politics. The role of immigration in shaping natives' voting behavior. J Public Econ 136:1-13

Bauer T, Lofstrom M, Zimmermann KF (2000) Immigration policy, assimilation of immigrants, and natives' sentiments towards immigrants: evidence from 12 OECD countries. Swedish Econ Pol Rev 7:11-53

Becker SO, Fetzer T (2016) Does migration cause extrame voting? Tech. rep., CAGE Working Paper

Betz H-G (2008) Islam and the far right. In: Davies P, Johnson P (eds) The far right in europe: an encyclopedia. Greenwood World Publishing, Oxford

Borjas GJ (2006) Native internal migration and the labor market impact of immigration. J Hum Res 41(2):221-258

Borjas GJ, Freeman RB, Katz LF (1996) Searching for the effect of immigration on the labor market. Am Econ Rev 86(2):246-251

Brunner B, Kuhn A (2018) Immigration, cultural distance and natives' attitudes towards immigrants: evidence from Swiss voting results. KYKLOS 71(1):28-58

Card D (2001) Immigrant inflows, native outflows, and the local labor market impacts of higher immigration. J Labor Econ 19(1):22-64

Card D (2009) HOw immigration affects U.S. cities. In: Inman R (ed) Urban enigma: city problems, city prospects. Princeton University Press, Princeton, NJ

Carter E. (2005) The extreme right in Western Europe. Manchester University Press, New York, NY

Cortes P (2008) The effects of low-skilled immigration on U.S. Prices: evidence from CPI data. J Polit Econ 116(3):381-422

Davies P. (2008) Introduction. In: Davies P., Johnson P (eds) The far right in Europe: an encyclopedia. Greenwood World Publishing, Oxford

Dülmer H, Klein M (2005) Extreme right-wing voting in Germany in a multilevel perspective: a rejoinder to Lubbers and Scheepers. European J Polit Res 44:243-263

Dustmann C, Preston I (2007) Racial and economic factors in attitudes to immigration. B.E. J Econ Anal Pol 7(1):Art. 62

Dustmann C, Vasiljeva K, Damm AP (2019) Refugee migration and electoral outcomes. Rev Econ Stud 86(5):2035-2091

Edo A, Giesing Y, Öztunc J, Poutvaara P (2019) Immigration and electoral support for the far-left and the far-right. European Econ Rev 115:99-143

Ellinas AA (2010) The media and the far right in Western Europe: playing the nationalist card. Cambridge University Press, New York, NY

Esipova N, Ray J, Pugliese A (2015) HOw the world views migration. Tech. rep., International Organization for Migration (IOM). Geneva 
Eurostat (2020) Immigration: Total number of long-term immigrants arriving into the reporting country (2007-2018). https://ec.europa.eu/eurostat/databrowser/view/tps00176/default/bar?lang=en

Facchini G, Mayda AM (2009) Does the welfare state affect individual attitudes toward immigrants? Evidence across countries. Rev Econ Stat 91(2):295-314

Facchini G, Mayda AM (2012) Does the welfare state affect individual attitudes toward immigrants? Evidence across countries. World Econ 35(2):183-196

Gerdes C, Wadensjö E (2008) The impact of immigration on election outcomes in Danish municipalities. Tech. rep., IZA Discussion Paper Series, No. 3586

Giuntella O, Mazzonna F, Nicodemo C, Vargas-Silva C (2019) Immigration and the reallocation of work health risks. J Popul Econ 32(3):1009-1042

Giuntella O, Nicodemo C, Vargas-Silva C (2018) The effects of immigration on NHS waiting times. J Health Econ 58:123-143

Golder M (2003) Explaining variation in the success of extreme right parties in Western Europe. Comp Polit Stud 36(4):432-466

Goodwin M (2008) The far right in the twenty-first century. In: Davies P, Johnson P (eds) The far right in europe: an encyclopedia. Greenwood World Publishing, Oxford

Gozdecka DA (2013) NAturalisation procedures for immigrants: Finland. Tech. rep., EUDO Cirizenship Observatory, Badia Fiesolana, San Domenico di Fiesola (FI), Italy

Halla M, Wagner AF, Zweimüller (2017) Immigration and voting for the far right. J European Econ Assoc 15(46):1341-1385

Harmon NA (2018) Immigration, ethnic diversity and political outcomes: evidence from Denmark. Scandinavian J Econ 120(4):1043-1074

Hopkins DJ (2010) Politicized places: explaining where and when immigrants provoke local opposition. Am Polit Sci Rev 104(1):40-60

Hytti H, Paananen S (2003) Foreign citizens in Finland as recipients of social security benefits. Yearb Popul Res Finl 39:73-90

Ignazi P (2003) EXtreme right parties in Western Europe. Oxford University Press, New York, NY

Jaakkola M (2000) Finnish attitudes towards immigrants in 1987-1999. Yearb Popul Res Finl 36:129-161

Jaeger DA, Ruist J, Stuhler J (2018) Shift-share instruments and the impact of immigration. Tech. rep., IZA Discussion Paper Series, No. 11307

Kitschelt H, McGann A (1995) The radical right in Western Europe. A comparative analysis. University of Michigan Press, Ann Arbor, MI

Koivukangas O (2003) European immigration and integration: Finland. Tech. rep., National Europe Center Paper No. 63

Levi E, Dasi Mariani R, Patriarca R (2020) Hate at first sight? Dynamic aspects of the electoral impact of migration: the case of ukip. J Popul Econ 33(1):1-32

Mayda AM (2006) Who is against immigration? A cross-country investigation of individual attitudes toward immigrants. Rev Econ Stat 88(3):510-530

Mendez I, Cutillas IM (2014) Has immigration affected Spanish presidential elections results? J Popul Econ 27:135-171

Messina AM (2007) The logics and politics of post-WWII migration to Western Europe. Cambridge University Press, New York, NY

Ministry of Justice (2010) Finnish election system: overview. https://oikeusministerio.fi/material/ attachments/om/julkaisut/6Fioq3rxv/OMTH_72_2010_Finnish_Election_System__Overview_32_s.pdf

Mudde C (2007) Populist radical right parties in Europe. Cambridge University Press, New York, NY

Niemi MK (2012) MEssenger and defender - Timo Soini's populist leadership and media strategies in winning the elections of 2011. Res Finnish Soc 5:7-17

Norocel OC (2016) Finland: from agrarian to right-wing populism. In: Aalberg T, Esser F, Reinmannand C, Stromback J, de Vresse CH (eds) Populist political communication in Europe. Routledge, New York, NY

Nunziata L (2015) Immigration and crime: evidence from victimization data. J Popul Econ 28:697-736

Olzak S (1992) The dynamics of ethnic competition and conflict. Standford University Press, Stanford

O'Rourke KH, Sinnott R (2006) The determinants of individual attitudes towards immigration. European J Polit Econ 22:838-861

Orrenius PM, Zavodny M (2015) Does immigration affect whether us natives major in science and engineering? J Labor Econ 33(S1):S79-S108 
Otto AH, Steinhardt MF (2014) Immigration and election outcomes - evidence from city districts in Hamburg. Reg Sci Urban Econ 45:67-79

Peri G, Sparber C (2011) Assessing inherent model bias: an application to native displacement in response to immigration. J Urban Econ 69(1):82-91

Pytliková M (2014) The effect of EU enlargement and labour market openings on migration. Tech. Rep. Working paper

Roxburgh A (2002) Preachers of hate: the rise of the far right. WS bookwell, London, GB

Sá F (2014) Immigration and house prices in the UK. Econ J 125:1393-1424

Sarvimäki M (2011) Assimulation to a welfare state: labor market performance and use of social benefits by immigrants in Finland. Scandinavian J Econ 113(3):665-688

Scheve KF, Slaughter MJ (2001) Labor market competition and individual preferences over immigration policy. Rev Econ Stat 83:133-145

Sherif M, Harvey OJ, J, WB, Hood W, Sherif CW (1961) Intergroup conflict and cooperation: the robbers cave experiment. The University Book Exchange, Norman, OK

Slotwinski M, Stutzer A (2019) The deterrent effect of an anti-minaret vote on foreigners' location choices. J Popul Econ 32(3):1043-1095

Statistics Finland (2016) Metadata: population structure. https://www.stat.fi/meta/til/vaerak_en.html

Steinmayr A (2018) Contact matters: exposure to refugees and voting for the far-right. Technical Report. Working paper

Swank D, Betz H-G (2002) Globalization, the welfare state and right-wing populism in Western Europe. Socio Econ Rev 1:215-245

Triandafyllidou A, Gropas R (2008) European immigration: a sourcebook. Ashgate Publishing Ltd, Farnham, GB

Westinen J (2014) A shock for stability? Testing for persistence of electoral geography in volatile elections. Scandinavian Polit Stud 37(2):123-148

Yla-Anttila T, Yla-Anttila T (2015) Exploiting the discursive opportunity of the euro crisis: The rise of the finns party. In: Kriesi H, Pappas TS (eds) European populism in the shadow of the great recession. ECPR Press, Colchester, UK

Zimmermann KF (2019) Social cohesion and labor mobility. In: Nationalbank O (ed) Economic and monetary union - deepening and convergence. 45th economics conference 2018. Oesterreichische Nationalbank, Vienna, pp 77-80

Publisher's note Springer Nature remains neutral with regard to jurisdictional claims in published maps and institutional affiliations. 